\title{
Okullarda Akran Zorbalığı: Öğretmen Görüşlerine Göre Nitel Bir Çalışma1
}

\author{
DOI: 10.26466/opus.644848 \\ $*$ \\ Ersoy Çark1t ${ }^{*}$ - Feride Bacanl1 ${ }^{* *}$ \\ * Arş. Gör., Nevşehir Hacı Bektaş Veli Üniversitesi, Eğitim Fak. Nevşehir / Türkiye \\ E-Posta: carkitersoy@nevsehir.edu.trＯORCID: 0000-0002-9811-9135 \\ ** Prof. Dr. Gazi Üniversitesi, Gazi Eğitim Fakültesi Ankara/ Türkiye \\ E-Posta: ferbacanli@gmail.com \\ ORCID: 0000-0001-9626-3734
}

Öz

Bu araştırmanın amacı, ilkokullarda ve ortaokullarda yaşanan akran zorbalı̆̆ını, öğretmen görüşlerine göre incelemektir Bu araştırma, temel nitel betimsel desen ile yürütülmüştür. Çalışma grubu, ilk ve ortaokullarda görev yapan 26'sl $(\% 81,25)$ kadın, 6'sl (\%18,75) erkek toplam 32 öğretmenden oluşmaktadır. Araştırmada veri toplamak için araştırmacılar tarafından geliştirilen Okullarda Akran Zorbalığ Anketi kullanılmıştır. Ankete araştırmanın amacı, akran zorbalığ ve akran zorbalığının özellikleri hakkında kısa bilgi notu yazılmış ve öğretmen görüşleriyle ilgili 2 kapalı uçlu 9 açık uçlu soru sorulmuştur. Araştırma verileri içerik ve betimsel analiz yöntemleri kullanılarak çözümlenmiştir. Araştırma sonuçları akran zorbalığının ilk ve ortaokullarda çok yaygın bir sorun olduğunu, çoğunlukla fiziksel ve sözel zorbalığın yaşandığını göstermiştir. Ailesel faktörler akran zorbalığının en önemli nedeni olarak belirtilmiştir. Öğretmenler zorbalıkla baş etmede başvurdukları ilk kaynağın okul psikolojik danışma ve rehberlik servisleri olduğunu belirtmişlerdir. Araştırmanın sonuçları ilgili literatür çerçevesinde tartışılmış, araştırmanın sınırlılıkları belirtilmiş, gelecekte yapılacak uygulamah ve teorik araştırmalar için öneriler sunulmuştur.

Anahtar Kelimeler: Akran zorbalı̆̆l, zorba, kurban, öğretmen

\footnotetext{
${ }^{1}$ Bu çalışma 25-27 Ekim 2018 tarihlerinde düzenlenen 20.Uluslararasın Psikolojik Danışma ve Rehberlik Kongresi'nde sözlü bildiri olarak sunulmuştur.
} 


\title{
Peer Bullying in Schools: A Qualitative Study According to Teachers Views
}

\begin{abstract}
The purpose of this research is to examine peer bullying in primary and secondary schools according to opinions of teachers. This research was carried out with the basic qualitative describtive method. The study group consists of 32 teachers, consisting of $26(81.25 \%)$ females and 6 (18.75\%) males working in different primary and secondary schools. The Peer Bullying Questionnaire in Schools developed by researchers was used to collect data in the research. A short information note about the purpose of the research, the characteristics of peer bullying and peer bullying were written on the questionnaire form, and 2 closed-ended and 9 open-ended questions were asked about teacher opinions. Research data were analyzed using content analysis and descriptive analysis methods. Research results have shown that peer bullying is a very common problem in primary and secondary schools, mostly physical and verbal bullying. Familial factors are stated as the most important reason of peer bullying. It has been determined that the guidance services are the first resource that teachers use to deal with bullying. The results are discussed within the framework of the literature, the limitations of the research are specified, and suggestions for future practical and theoretical research are presented.
\end{abstract}

Keywords: Peer bullying, bully, victim, teacher. 


\section{Giriş}

Okul zorbalığı, okul şiddetinin en yaygın tipidir. Zorbalık, bir çocuğun başka bir çocuğa fiziksel ve sözel olarak ya da sanal bir ortamda zarar verecek davranışlar sergilemesi olarak tanımlanmaktadır (Olweus, 2005). Zorbalık yapan kişi zorba, zorbalığa maruz kalan kişi mağdur veya kurban olarak adlandırılmaktadır. Bazı bilimsel araştırmalar zorbalığın ciddi zihinsel ve fiziksel sorunlara yol açtığını göstermektedir (Morita, 1985). Okul zorbalığı ergenlik ve çocukluk dönemlerinin normal ve zararsız davranışları olarak da görülmektedir. Bununla birlikte zorbalığa uğrayan mağdur/kurban çocukların okulda mutsuzluk ve güvensizlik hisleri, okul fobisi, depresyon, kaygı, uyku güçlükleri, gece yatak ıslatması gibi klinik yardım gerektiren sorunlar yaşadıkları rapor edilmiştir (Cole vd., 2016; Östberg, Modin ve Låftman, 2018). Ayrıca zorbalığa maruz kalan çocukların düşük benlik saygısına ve somatik belirtilere sahip oldukları, yalnızlık ve yalıtılmışlık yaşadıkları görülmüştür (Boulton ve Underwood, 1992; Schwartz, 2000; Williams, Chambers, Logan ve Robinson, 1996). Bunlara ilaveten zorbalığa uğrayan öğrencilerin intihar, kaygı ve depresyon gibi psikolojik problemler yaşadıkları ve okuldan kaçma, okul terki, zor öğrenme gibi davranışlar gösterdikleri belirlenmiştir (Greenbaum, Turner ve Stephens, 1988; Olweus, 1993; Rigby ve Slee, 1999).

Ülkemizde yapılan araştırmalarda zorbalığa maruz kalan çocukların kaygı, içe yönelen öfke, çaresizlik, değersizlik, yalnızlık gibi olumsuz duyguları yoğun olarak yaşadıkları belirlenmiştir (Atik ve Kemer, 2008). Zorbalığa maruz kalan çocukların benlik saygılarının düşük olduğu (Tural Hesapçıŏlu, Yeşilova Meraler ve Ercan, 2018), okula gitmek istememe ve düşük akademik başarı gibi sorunlar yaşadıkları da (Atik, 2006; Gökler, 2009) rapor etmişlerdir. Yurt dışında zorbalıkla ilgili çeşitli araştırmalarda zorba öğrencilerin okuldan kaçma, kurallara uymama, diğerlerine karşı saldırgan eylem ve öfke gösterme gibi davranışlar gösterdikleri bulunmuştur (Jacobs, 2008; Menesini vd., 2003). Çeşitli araştırmaların sonuçları da, okul yıllarında zorbalık yapan çocuk ve ergenlerin yetişkinliklerinde suç ve şiddet olaylarına karışma, dürtüsel ve riskli davranışlarda bulunma (Forero, McLellan, Rissel ve Bauman 1999; Kaltiala-Heino, Rimpela, Rantanen ve Rimpela, 2000), iş hayatlarında başarısız olma ve madde kullanımıyla ilgili sorunlar yaşama açısından daha fazla risk taşıdıklarını (Bender ve Lösel, 2011; Kim, 
Catalano, Haggerty ve Abbott, 2011) göstermiştir. Hazler, Hoover ve Oliver, (1992) ve Olweus (1993) çocuklukta zorbalığa maruz kalmanın yetişkinlik yıllarını olumsuz etklediğini ve bu olumsuz yaşantıların kişilerin başkalarıyla olumlu ilişkiler kurma ve geliştirme becerilerini zedelediğini rapor etmişlerdir. Hatta çocukluğunda zorbalığa maruz kalanların yetişkinlikte anti-sosyal davranışları ve yasal olmayan problem davranışları sergiledikleri rapor edilmiştir (Olweus, 1994; Salmon, James ve Smith, 1996).

Günümüzde okul zorbalığı araştırmacılar tarafından bir problem davranış olarak kabul edilmektedir. Bu görüşlere dayanılarak zorba davranışın hangi davranışların oluşmasına ve gelişmesine yol açtığını ve zorbalığın nedenlerini araştıran çalışmalar yapılmıştır (Due vd., 2005; Kim, Leventhal, Koh, Hubbard ve Boyce, 2006; Smith, 2016). Örneğin zorbalığa uğrayan çocuklara yapılan fiziksel, psikolojik ve duygusal zarar vermenin yayginl1ğını inceleyen çeşitli araştırmalar bulunmaktadır (Greenbaum vd., 1988; Rigby ve Slee, 1991; Salmon, James, Cassidy ve Javaloyes, 2000; Zych, Farrington, Llorent ve Ttofi, 2017). Bu çalışmalara paralel bir şekilde okulda zorbalığı önleme çalışmalarının da aynı hızda sürdürüldüğü söylenebilir (Brown, Low, Smith ve Haggerty, 2011; Chatters ve Zalaquett, 2018; Gökkaya ve Tekinsav Sütcü, 2018a).

Türkiye'de okul zorbalığı konusundaki araştırılmaların yurt dışındaki ülkelere göre daha geç başlatıldığı söylenebilir. Fakat ülkemizde de özellikle son yıllarda okul zorbalığıyla ilgili çalışmaların giderek arttı̆̆ görülmektedir (örn., Bilgin, 2007; Danacı ve Çetin, 2016; Gültekin Akduman, 2010; Hilooğlu ve Cenkseven-Önder, 2010; Kartal ve Bilgin, 2009; Tepetaş, Akgün ve Akbaba-Altun, 2010; Yalçıntaş Sezgin, 2018). Ülkemizde okul zorbalığı konusundaki çalışmalarda daha çok okul zorbalığının nedenlerinin (Akca, Sayımer, Salı ve Başak, 2014; Kartal ve Bilgin, 2012), ilişkili olduğu değişkenlerin (Ayas ve Pişkin, 2011; Bedel ve Güler, 2020; Gür, Eray, Makinecioğlu, Sığırlı ve Vural, 2020), gelişim dönemine veya sinıf düzeyine göre farklılaşmasının (Ayas ve Pişkin, 2011; Horzum ve Ayas, 2011) veya benzerlerinin araştırıldığı söylenebilir. Bununla birlikte okul zorbalığının önlenebilmesi veya zorbalıkla başa çıkabilmek için okul ortamında öncelikle zorbalığa tanık olan öğrencilerin, öğretmenlerin, okul yöneticilerinin, okuldaki diğer görevlilerin, hatta ebeveynlerin okul zorbalığınıa ilşkin görüşlerinin araştırılmasının önemli olduğu düşünülmektedir. 
Yurt dışında ve ülkemizde zorbalıkla ilgili literatürde zorbalığa tanık olan öğrencilerle ilgili de çeşitli araştırmalar yapılmıştır (Espelage, 2018; Jenkins ve Nickerson, 2019; Kurt Demirbaş ve Öztemel, 2019). Öğrenciler dişında zorbalığa en çok tanık olan kişiler öğretmenler ve yöneticilerdir. Yurt dışında öğretmen (Dake, Price ve Telljohann, 2003; Dake, Price, Telljohann ve Funk, 2003; Stauffer, Heath, Coyne ve Ferrin, 2012; Yoon, 2004) ve yöneticilerin ve hatta ebeveynlerin (Peyton, 2015) zorbalık hakındaki görüşlerini araştıran çalışmalar yapılmıştır. Ülkemizde de okul yöneticilerinin ve öğretmenlerin zorbalıkla ilgili görüşlerinin incelendiği (Aksoy, 2019; Hoşgörür ve Orhan, 2017; İnandı ve Yıldız, 2014; Serin, 2012) araştırmaların çok az ve bu araştırmaların da daha çok betimsel nicel yöntemlerle çalışılan araştırmalar oldukları, nitel yöntemle çalışılan araştırmaların ise sayılabilecek kadar az (Atış Akyol, Yıldız ve Akman, 2018) olduğu söylenebilir.

$\mathrm{Bu}$ araştırmalara rağmen öğrenci merkezli eğitim yaklaşımının iyice yerleştirilmeye çalışıldığı ülkemizde bu yaklaşımın, okul ikliminin mimarı öğretmen ve okul yöneticilerinin rol ve fonksiyonlarının yeniden gözden geçirilmesini gerektirmiştir. Kısacası günümüz öğretmeni öğretici fonksiyonunun yanı sıra olumlu kişilik geliştirmeden de sorumludur (Hilliard, Batanova ve Bowers, 2015). Dolayısıyla öğretmen öğrenci ilişkilerinin önemli olduğu (Çelik, Toraman ve Çelik, 2018; Demirtaş, 2010; Gurbetoğlu ve Tomakin, 2011) ve okul zorbalığının giderek arttı̆̆ı günümüzde (Gökkaya ve Tekinsav Sütcü, 2018b) ilkokul ve ortaokullardaki okul zorbalığına ilişkin öğretmen görüşlerinin temel nitel betimsel desen kullanarak günümüz koşullarında incelenmesi gereksinimi ortaya çıkmaktadır. Nitel betimsel desen ile tasarlanan araştırmalar olgubilim deseninin tonlarımı taşımakla beraber, amaç görüş ve deneyimlerin derin anlamlarını çıkarmak değil, katılımcı görüşlerini betimleyici bir özetle sunmaktır (Sandelowski, 2000, s. 337). Nitel betimsel çalışmaların olgubilim çalışmalarına kıyasla yorumlayıcılık özelliği daha azdır. Bununla birlikte nitel betimsel araştırmalar, teori oluşturma veya olgubilim çalışmaları için alt yapı oluşturmaktadır (Sandelowski, 2000, 2010). Bu nedenle bu araştırmanin amacı, okul ve sınıf ortamında karşılaşılan zorbalık sıklığı, okulda ne tür zorba davranışlarla karşılaşıldığı, öğrencilerin hangi durumlarda zorba davranışlar yaptıkları, zorbalığa uğrayan öğrencilerin neler yaptıkları, zorbalığa tanık olan öğrencilerin neler yaptıkları, zorbalık karşısında öğretmenlerin neler yaptıkları, zorba davranışların nedenlerinin neler olduğu, zorbalık yapan çocukların özellikleri ile ilgili 
öğretmen görüşlerini temel nitel betimsel desen yöntemiyle incelemek amaçlanmıştır. Bunlara ilaveten, öğretmenlerin zorbalığı önlemek için neler yapılması gerektiğine ve zorbalıkla başetme konusunda nasıl yardım temin ettiklerine ilişkin görüşlerini temel nitel betimsel desen yöntemiyle incelemek amaçlanmıştır. Bu araştırmanın sonuçları, öncelikle günümüz ilkokul ve ortaokul ögretmenlerinin okul ortamında ve sinif ortamında okul zorbalığına ilişkin görüşlerinin belirlenmesini sağlayacaktır. Ayrıca, bu araştırmanın sonuçlarının günümüzde ilkokul ve ortaokullarda hangi tür zorba davranışların hangi sıklıkla yapıldıkları, zorba davranışa uğrayan/madur öğrencilerin ve zorbalığa tanık olan öğretmenlerin neler yaptıkları hakkında güncel ve derin bilgiler sunacaktır. Tüm bu bilgilerin ilkokul ve ortaokul kurumlarında, okul ve sınıf ortamlarında yapılan zorba davranışları önleme konusunda oldukça güncel bulgular sunacağ 1 beklenmektedir. Bu güncel bulgularının bir yandan okullarda ve sinıflarda zorbalığı önlemek için gelecekte yapılacak teorik ve uygulamalı araştırmalar için önemli doğurgular sunacağı beklenmektedir. Diğer yandan bu araştırmanın bulgularının 20192020 eğitim-öğretim yılı için Milli Eğitim Bakanlığı'nın ulusal düzeyde okullarda şiddeti önleme çalışmaları kapsamında yer alan okul zorbalığı ile ilgili teorik ve uygulamalı çalışmalara güncel veriler sunacağı beklenmektedir.

\section{Yöntem}

Bu araştırmada okullarda yaşanan akran zorbalığı hakkında öğretmen görüşlerini incelemek ve betimlemek amaçlanmıştır. Bu amaca hizmet etmesi bakımından araştırmanın deseni temel nitel betimsel desendir. Bu desende amaç, bir olgunun doğrudan ve basit betimlemesini sunmaktır (Lambert ve Lambert, 2012; Sandelowski, 2010). Diğer bir ifadeyle bu desenin amacı bireylerin bir vaka veya olguyla ilgili düşüncelerini tanımlayarak betimlemektir (Willis, SullivanBolyai, Knafl ve Cohen, 2016). Sandelowski'e (2000) göre nitel betimleme araştırmaları olgubilim araştırmalarına kıyasla daha az yorumlayıcllı özelliğine sahip olsa bile olgubilim deseni gibi diğer nitel desenlerin özelliklerine de sahiptir. 


\section{Çalışma Grubu}

Çalışma grubu amaçlı örnekleme yöntemlerinden tipik durum örnekleme yöntemi kullanılarak oluşturulmuştur. Amaçlı örnekleme, çalışmanın amacı doğrultusunda zengin bilgi içeriğine sahip durumların seçilmesidir. Tipik durum örnekleme ise evrende yer alan birçok durumdan sıradışı olmayan bir durumun belirlenmesidir (Büyüköztürk, Çakmak, Akgün, Karadeniz ve Demirel, 2013). Çalışma grubu, 26'sı kadın ve 6'sı erkek olmak üzere toplam 32 öğretmenden oluşmaktadır. Bu öğretmenlerden 17'si Ankara il merkezindeki bir ilkokul ve ortaokulda görev yapmaktadırlar. Öğretmenlerden $15^{\prime} \mathrm{i}$ ise Kahramanmaraş-Afşin ilçesindeki ilkokul ve ortaokulda görev yapmaktadırlar. Katılımcıların 28'i lisans, 4'ü lisansüstü mezunudur. Öğretmenlerin 20'si 1-10 yıl arası, 9'u 11-20 yıl arası ve 3'ü 21 yıl ve üstü süredir öğretmenlik yapmaktadır. Katılımcıların 15'i sınıf öğretmeni, 3'ü Türkçe öğretmeni, 1'i sosyal bilgiler öğretmeni, 2'si matematik öğretmeni, 1'i bilişim teknolojileri öğretmeni, 1'i fen bilimleri öğretmeni ve 1'i resim öğretmeni iken 8 katılımcı branşını belirtmemiştir.

\section{Veri Toplama Aract ve Verilerin Toplanması}

Araştırmada veri toplama aracı olarak araştırmacılar tarafından geliştirilen, alınan uzman görüşlerine göre son hali verilen ve iki bölümden oluşan 'Okullarda Akran Zorbalığı Anketi' kullanılmıştır. Birinci bölümde demografik bilgilerle ilgili sorular, çalışmanın amacı, akran zorbalığnın tanımı, özellikleri ve türleriyle ilgili bilgi notu bulunmaktadır. İkinci bölümde ise akran zorbalığına ilişkin öğretmenlere yönelik 2 kapalı 9 açık uçlu olmak üzere 11 adet farklı türde sorular soru bulunmaktadır. Farklı türden sorular, katılımcıların, farklı düşünme biçimlerine hitap edecektir. Üstelik aynı soru türünü kullanmak, sıkıcı olabileceği gibi derinlemesine ve detaylı veriler elde etmede sorun yaratabilir (Yıldırım ve Şimşek, 2013). Anket formu, katılım konusunda gönüllü ve halen görev yapmakta olan öğretmenlerden toplanmıştır. Bir anketin cevaplanma süresi yaklaşık 20-25 dakika sürmüştür. Ankette bulunan sorular aşağıda verilmiştir.

1. Okulunuzda zorbalık davranışlarıyla karşılaşıyor musunuz?"

2. Sınıfınızda zorbalık davranışlarıyla karşılaşıyor musunuz? "

3. Okulunuzda ne tür zorbalık davranışlarıyla karşılaşıyorsunuz?" 
4. Öğrenciler hangi durumlarda zorbalık yapmaktadır?"

5. Zorbalığa uğrayan öğrenciler genellikle neler yapmaktadır?"

6. Zorbalığa tanık olan öğrenciler genellikle neler yapmaktadır?"

7. Zorbalığa tanık olunca siz öğretmen olarak neler yapmaktasınız?"

8. Zorba davranışların nedenlerinin neler olduğunu düşünüyorsunuz?"

9. Zorbalığı yapan öğrencilerin özellikleri nelerdir?"

10. Zorbalığın önlenmesi için neler yapılması gerektiğini düşünüyorsunuz?"

11. Zorbalıkla baş etme konusunda ihtiyacınız olan yardımı nasıl temin etmektesiniz?"

\section{Verilerin Analizi}

$\mathrm{Bu}$ araştırmada anket formundaki sorulara verilen cevaplar içerik analizi ve betimsel analizleri yapılarak çözümlenmiştir. İçerik analizi, içerik ve bağlam bakımından benzer verileri belirli kavram ve temalar çerçevesinde bir araya getirerek anlaşılması kolay biçimde düzenlemek, ifade etmek ve yorumlamaktır (Yıldırım ve Şimşek, 2013). Betimsel analiz ise nitel verileri özetlemeyi ve yorumlamayı içeren nitel analiz türüdür (Yıldırım ve Şimşek, 2013). Bu araştırmada veriler nitel analiz teknikleriyle çözümlenmiştir. Fakat bu nitel veriler Yıldırım ve Şimşek'in (2013, s. 274-275) görüşlerine dayanılarak bulgular bölümünde tablolarla ve nicelleştirilerek sunulmuştur. Daha açık bir anlatımla bu araştırma sonuçları kodların sıklığını gösterecek biçimde tablolaştırılarak sunulmuştur. Çünkü Yıldırım ve Şimşek'e (2013, s. 274-275) göre nicelleştirme (sayılara dökme) nitel bulguların açıklı̆ını, anlaşılabilirliğini ve güvenirliğini artırmak için kullanılabilir. Ayrıca bu araştırmada Lincoln ve Guba'nın (1985) görüşlerine dayanılarak geçerlik ve güvenirlik için bazı önlemler alınmıştır. Bu araştırmacıların da önerdiği gibi araştırmanın aktarılabilirliğini sağlamak için amaçlı örnekleme yöntemi kullanılmış ve katılımc1 görüşleri doğrudan alıntılabilir şekilde verilmiştir. İnandırıcılık için farklı kurumlarda görev yapan ve farklı branşlardaki öğretmenlerden veriler toplanmıştır. Ayrıca araştırma alanda uzman bir kişi tarafından incelenmiştir. Tutarlık için veri analizi sürecinde araştırmacılar ortak görüşlere ulaşana dek tartışarak süreci tamamlamışlardır. İhtiyaç halinde teyit edilebilirlik için araştırma kapsamında toplanan veriler ve kodlamalar muhafaza edilmektedir. 


\section{Bulgular}

Bu bölümde içerik analizi ve betimsel analiz sonuçlarında ortaya çıkan bulgular, tablolarda frekans değerleri verilerek sunulmuştur. Araştırma bulguları incelenirken katılımcıların görüşlerine ilişkin doğrudan alıntılara yer verilmiş ve bu süreçte katılımcıların gerçek isimleri kullanılmamıştır. Bunun yerine her bir katılımciyı temsil eden ayrı bir kod belirlenmiş (Ö1, Ö2, Ö3... vb.), bulgularda sunulan katılımc görüşlerinde bu kodlar kullanılmıştır.

Aşağıda bu araştırmada öğretmenlerin anket formundaki sorulara verdiği cevaplar tablolarda ve nicelleştirilerek sunulmuştur. Anket formundaki 1 ve 2.soru 1.tabloda birlikte sunulmuştur (bakınız. Sayfa 9: Araştırmadaki anket sorulari)

Tablo 1. Öğretmenlerin, okullarında ve sınflarında zorbalıkla karşılaşma durumuna ilişkin görüşleri

\begin{tabular}{lrr}
\hline & Evet & Hayır \\
\hline Okulunuzda zorbalık davranı̧larılyla karşılaşıyor musunuz? & 28 & 4 \\
\hline Sinıfinızda zorbalık davranışlarılyla karşılaşıyor musunuz? & 29 & 3 \\
\hline
\end{tabular}

Tablo 1 incelendiğinde, araştırmaya katılan öğretmenlerden 28 kişi okulunda, 29 kişi ise sınıfında zorbalık davranışlarıyla karşılaştığını belirttiği görülmektedir.

Tablo 2. Öğretmenlerin, okullarında hangi tür zorbalıklarla karşılaştıklarına ilişkin görüşleri

\begin{tabular}{lc}
\hline Kategoriler & $\mathbf{f}$ \\
\hline Fiziksel zorbalık (tekme atma, vurma, itme, saç çekme) & 31 \\
\hline Sözel zorbalık (lakap takma, alay etme, hakaret etme, küfür etme, laf atma) & 30 \\
\hline Dışlama & 15 \\
\hline Taciz & 3 \\
\hline Eşyalarını izinsiz kullanma & 3 \\
\hline Siber zorbalık & 2 \\
\hline Paralarını zorla alma & 2 \\
\hline Kantinden zorla bir şeyler aldırma & 1 \\
\hline
\end{tabular}

Tablo 2 incelendiğinde, öğretmenlerin okullarda karşılaşılan zorbalık türlerini sırasıyla; fiziksel zorbalık ve sözel zorbalık olarak belirttiği görülmektedir. Devamında ise dışlama, taciz, eşyalarını izinsiz kullanma, siber zorbalık, paralarını zorla alma ve kantinden zorla bir şeyler aldırma olarak ifade 
edilmektedir. Öğrencilerin sergilediği zorbalık davranışlarını katılımcılardan Ö8; 'Genel olarak fiziksel ve sözel zorbalıkla karşılaştığımı söyleyebilirim. Fiziksel olarak; vurma, itme, bir şeyler firlatma örnek gösterilebilir. Sözel olarak ise küfür etme, laf atma belirtilebilir.' ve Ö15: 'İsim takma, gruptan dışlama benim en çok gördüklerim.' şeklinde ifade etmişlerdir.

Tablo 3. Öğretmenlerin, öğrencilerin hangi durumlarda zorbalık yaptıklarına ilişkin görüşleri

\begin{tabular}{ll}
\hline Kategoriler & $\mathbf{f}$ \\
\hline Oyun esnasında & 6 \\
\hline Aynı fikirde olmadıklarında & 4 \\
\hline Dikkat çekmek istendiğinde & 3 \\
\hline Başarılı ögrenciyi kıskandıklarında & 3 \\
\hline İstekleri olmayınca & 2 \\
\hline Lider olmak istediklerinde & 2 \\
\hline Kendini ifade edemediklerinde & 2 \\
\hline Öfkelendiklerinde & 1 \\
\hline İstemedikleri şeye zorlandıklarında & 1 \\
\hline Arkadaş ilişkileri bozulunca & 1 \\
\hline
\end{tabular}

Tablo 3 incelendiğinde öğretmenler sırayla; oyun esnasında, ayn fikirde olmadıklarında, öğrenci dikkat çekmek istediği zaman, başarılı olan öğrenciyi kıskandıklarında, istekleri olmayınca, lider olmak istediklerinde, kendilerini ifade edemediklerinde, öfkelendiklerinde, istemedikleri bir şeyi yapmaya zorlandıklarında ve arkadaş ilişkileri bozulduğunda zorbalık davranışlarının yaşandığını belirtmektedirler. Öğrencilerin hangi durumlarda zorba davranışlar sergilendiğine yönelik soruya katılımcılardan Ö25; 'Anlaşamadikları durumlarda vurmayı ve kavga etmeyi tercih ediyorlar.' ve Ö19; 'Oyun oynarken ufak bir anlaşmazlikta şiddetle tepki verebiliyor ve kinlenip bunu sürekli hale getirebiliyorlar.' şeklinde cevap vermişlerdir.

Tablo 4 incelendiğinde, öğretmenler, zorbalığa maruz kalan öğrencilerin sırasıyla; öğretmenlere şikâyet ettiklerini, sessiz kaldıklarını, zorbaca karşılık verdiklerini, ailesine şikâyet ettiklerini, üzüntü/ağlama şeklinde tepki verdiklerini, arkadaş gruplarına söylediklerini, okuldan soğuduklarını, okul idaresine şikâyet ettiklerini ve başka birine zorbalık yaptıklarını ifade etmişlerdir. 
Tablo 4. Öğretmenlerin, zorbalı̆̆a maruz kalan öğrencilerin yaptıklarna ilişkin görüşleri

\begin{tabular}{lc}
\hline Kategoriler & $\mathbf{f}$ \\
\hline Öğretmene şikâyet ediyor & 13 \\
\hline Sessiz kalıyor & 13 \\
\hline Saldırganca karşılık veriyor & 12 \\
\hline Ailesine şikâyet & 5 \\
\hline Üzüntü/ağlama & 3 \\
\hline Arkadaş gruplarına söylüyorlar & 3 \\
\hline Okuldan soğuyor & 1 \\
\hline Okul idaresine şikâyet & 1 \\
\hline Başka birine zorbalık & 1 \\
\hline
\end{tabular}

Öğrencilerin zorbalık karşısındaki tepkileri katılımclardan Ö22; 'Zorbahı̆g maruz kalan öğrenci kendide zorba oluyor. Bizlere ve ailelerine şikâyet ediyorlar.', Ö1; 'Zorbah̆̆g uğrayan öğrenciler genelde susuyor, hiçbir şey yapmıyor, içine kapanıyor.' ve Ö31; 'Zorbalı̆̆a maruz kalan öğrenciler sürekli şikâyet ediyor bize. Sürekli şikâyet, şikâyet... Şikâyetleri bitmiyor. Her şikâyetin ardından bir zorbalık çıkıyor.' şeklinde ifade etmişlerdir.

Tablo 5. Öğretmenlerin, zorba davranışların nedenlerine ilişkin görüşleri

\begin{tabular}{lc}
\hline Kategoriler & f \\
\hline Ailesel faktörler & 28 \\
\hline Çevresel faktörler & 10 \\
\hline Sosyal medya ve televizyon etkisi & 4 \\
\hline Yanlış arkadaş seçimi & 3 \\
\hline Zorbalığa maruz kalmak & 2 \\
\hline Kendini ifade edebilme çabası & 2 \\
\hline Güçlü olduğunu ispat etme çabası & 2 \\
\hline İlgi çekme isteği & 1 \\
\hline Ergenliğin etkisi & 1 \\
\hline Savaştan çıkmış olma & 1 \\
\hline
\end{tabular}

Tablo 5'e gore öğretmenler, zorbalığa en fazla; ailesel faktörlerin, çevresel faktörlerin, sosyal medya ve televizyonun, yanlış arkadaş seçiminin, zorbalığa maruz kalmanın, kendini ifade edememenin, güçlü olduğunu ispat etmeye çalışmanın, ilgi çekme isteğinin, ergenliğin etkisinin ve savaştan çıkmış olmanın neden olduğunu ifade etmişlerdir. Zorbalığın nedenlerini katılımcılardan Ö3; 'Genel olarak incelersek aile içi sorunlardan, arkadaş çeoresinden ve yaşanılan toplumsal çevreden kaynaklanıyor diyebilirim.', Ö12; 'Aileden 
öğrenildiğini düşünüyorum.' ve Ö6; 'Öğrencilerin sosyal çevrelerinden (aile, mahalle) öğrendiklerini düşünüyorum. Sosyal medya ve televizyon yayınlarmın etkilerini de gözlemliyorum.' şeklinde ifade etmişlerdir.

Tablo 6. Öğretmenlerin, zorbalı̆̆a tanık olan öğrencilerin yaptıklarına ilişkin

\begin{tabular}{ll} 
görü̈şleri & f \\
\hline Kategoriler & 16 \\
\hline Sessiz kalıyor & 10 \\
\hline Zorbalı̆̆ı önlemeye çalı̧ıyorlar & 7 \\
\hline Öğretmene şikâyet & 7 \\
\hline Zorbalı̆̆a katıllyor & 3 \\
\hline Kurbanı savunuyor & 2 \\
\hline İdareye şikâyet & 1 \\
\hline Zorbayı aileye şikâyet (kurbanın ailesine) &
\end{tabular}

Tablo 6'ya göre öğretmenler, zorbalığa tanık olan öğrencilerin; sessiz kaldıklarını, zorbalığı önlemeye çalıştıklarını, öğretmene şikâyet ettiklerini, zorbalığa katıldıklarını, kurbanı savunduklarını, okul idaresine şikâyet ettiklerini ve zorbayı, kurbanın ailesine şikâyet ettiklerini ifade etmişlerdir. Zorbalığa tanık olan öğrencilerin tepkilerini, katılımcilardan Ö32; 'Tanık olan öğrencilerin neredeyse tamamma yakına karışmamayı tercih ediyor.', Ö11; 'Bazen sessiz kalıyor bazen de müdahale ediyorlar ve olayı öğretmenlere anlatmak istiyorlar.' ve Ö10; 'Diğer öğrenciler genellikle duruma müdahale etmemeyi tercih ediyorlar. Nadiren müdahale durumu gözlemliyorum.' Şeklinde ifade etmişlerdir.

Tablo 7'ye göre öğretmenler zorbalık karşısında sırasıyla; sözel uyarıda bulunduklarını, aile görüşmesi yaptıklarını, öğrenciler bireysel görüşme yaptıklarını, zorbayı rehberlik servisine yönlendirdiklerini, zorbaya özür dilettiklerini, okul idaresine yönlendirdiklerini, sorunu tespit etmeye çalı̧tıklarını, empatiyi öğrettiklerini, zorbaya kızdıklarını, zorbaya zorbalık yaptıklarını, uygun rol model olmaya çalıştıklarını, görmezden geldiklerini, doğru davranışı pekiştirdiklerini ve zorbayı sürekli gözlemleyerek takip ettiklerini belirtmişlerdir. 
Tablo 7. Öğretmenlerin, zorbalı̆̆a tanık olduklarında yaptıkları davranışlar

\begin{tabular}{ll}
\hline Kategoriler & $\mathbf{f}$ \\
\hline Uyarıyorum & 8 \\
\hline Aileyle görüşüyorum & 7 \\
\hline Öğrencilerle görüşüyorum & 7 \\
\hline Rehberlik servisine yönlendiriyorum (zorbayı) & 6 \\
\hline Zorbaya özür diletiyorum & 5 \\
\hline Okul idaresine yönlendiriyorum & 4 \\
\hline Sorunu tespit ediyorum & 4 \\
\hline Empatiyi öğretiyorum & 4 \\
\hline Zorbaya kızıyorum & 1 \\
\hline Zorbaya cezalandırıorum & 1 \\
\hline Uygun rol model oluyorum & 1 \\
\hline Görmezden geliyorum & 1 \\
\hline Doğru davranışı pekiştiriyorum & 1 \\
\hline Sürekli gözlem ve takip (zorbayı) & 1 \\
\hline
\end{tabular}

Zorbalık karşısındaki tepkilerine yönelik katılımcılardan Ö18; 'Bu davranışın yanlış olduğu noktasında uyarıyorum. Zorbalık yapan bir çocuğa empati yapmasını söylüyorum. Aym davranışla bir gün kendisinin de karşılaşabileceğini anlatıyorum.', Ö27, 'Durumu fark ettiğimde ilk olarak öğrencilerle görüşüyorum. Sonrasinda rehberlik servisine gönderiyorum görüşmesi için.' ve Ö20; 'Her iki tarafla da ayrıca konuşuyorum. Zorba öğrencinin yaptıklarmdan okul idaresini ve aileyi haberdar ediyorum.' şeklinde ifade etmişlerdir.

Tablo 8'e gore öğretmenler zorbalığı sırayla; ailesel sorun yaşayanların, fiziksel olarak iri olan çocukların, akademik başarısı düşük olanların, kendini doğru ifade edemeyenlerin, cinsiyeti erkek olanların, maddi sorun yaşayanların, yüksek öz güvenli olanların, saldırgan olanların, savaş tanı̆̆ı olanların ve maddi durumu iyi olanların yaptığını ifade etmişlerdir.

Zorba öğrencilerin özelliklerini katılımclardan Ö23; 'Bedensel gelişimi diğerlerine göre daha fazla olan öğrencilerde, akademik yönden zaynf ve sosyal faaliyetlerde yer almayan öğrencilerde görüyorum.' ve Ö16; 'Aile ilgisini az almış ve ailevi problemleri olan çocuklarm eğilimlerinin fazla olduğunu gözlemliyorum.' şeklinde ifade etmişlerdir. 
Tablo 8. Öğretmenlerin, zorba davranışları hangi özelliklere sahip çocukların yaptıklarına ilişkin görüşleri

\begin{tabular}{ll}
\hline Kategoriler & f \\
\hline $\begin{array}{l}\text { Ailesel sorun yaşayanlar (aile içi şiddet, maddi sorunlar, aile ilgisi ve } \\
\text { sevgisi görmeyen) }\end{array}$ & 21 \\
\hline Fiziksel olarak iri olanlar & 8 \\
\hline Düşük akademik başarısı olanlar & 4 \\
\hline Kendini doğru ifade edemeyenler & 4 \\
\hline Erkek çocukları & 3 \\
\hline Maddi sorun yaşayanlar & 3 \\
\hline Yüksek özgüvenli olanlar & 2 \\
\hline Saldırgan olanlar & 2 \\
\hline Savaş tanığı olanlar & 1 \\
\hline Maddi durumu iyi olanlar & 1 \\
\hline
\end{tabular}

Tablo 9'a göre öğretmenler zorbalıkla başa çkmak için ihtiyaç duydukları yardımı sırasıyla; rehberlik servislerinden, okul idaresinden, ailelerden, diğer öğretmenlerden ve psikologlardan aldıklarını belirtmişlerdir.

Tablo 9. Öğretmenlerin, zorbalıkla başa çıkmada başvurdukları kaynaklara ilişkin görüşleri

\begin{tabular}{lc}
\hline Kategoriler & f \\
\hline Rehberlik servisinden & 19 \\
\hline Okul idaresinden & 7 \\
\hline Ailelerden & 7 \\
\hline Öğretmen arkadaşlardan & 3 \\
\hline Psikolog & 1 \\
\hline
\end{tabular}

Zorbalıkla baş etmek için ihtiyaç duyulan yardımı sağlama kaynaklarını katılımcılardan Ö17; 'Kesinlikle PDR uzmanlarından sağlıyorum bu yardımı.' ve Ö28; 'Rehberlik servisinden yardim altyorum. Gerektiğinde veli ve okul idaresinden de yardım talep ediyorum.' şeklinde ifade etmişlerdir.

Tablo 10'a göre öğretmenler zorbalığı önlemek için sırayla; aile eğitiminin, ailelerle işbirliğinin, empati eğitiminin, psikososyal müdahalenin, problem çözme becerisi kazandırmanın, başarıyı tattırmanın, değerle eğitiminin, disiplin cezası vermenin, uygun rol model olmanın ve aile terapisinin gerekli olduğunu belirtmişlerdir. 
Tablo 10. Öğretmenlerin zorba davranışlan önlemek için neler yapılabileceğine ilişkin görüşleri

\begin{tabular}{ll}
\hline Kategoriler & $\mathbf{f}$ \\
\hline Aile eğitimi & 13 \\
\hline Aile ile iş işbirliği & 8 \\
\hline Empati eğitimi & 5 \\
\hline Psiko-sosyal müdahale programı & 3 \\
\hline Problem çözme becerisi kazandırma & 2 \\
\hline Başarıyı tattırmak & 2 \\
\hline Değerler eğitimi & 1 \\
\hline Disiplin cezası & 1 \\
\hline Uygun rol model olma & 1 \\
\hline Aile terapisi & 1 \\
\hline
\end{tabular}

Zorbalığın önlenebilmesi için neler yapılması gerektiğini katılımclardan Ö13; 'Sinnf öğretmeni ve aile işbirliği ve etkileşimi, iletişimi arttırlmalı. Sinıf öğretmenleri aile ile iç içe olmalı.', Ö23; 'Öğrencilere değerlerimizin öğretilmeli. Empati kurmayı ve olaylarn daha geniş değerlendirmeyi öğrenmeliler.' ve Ö8; 'ilk adım ailelerin eğitimi. Psiko-sosyal müdahaleler ve problem çözme becerilerinin öğretilmesi şart.' şeklinde ifade etmişlerdir.

\section{Tartışma ve Sonuç}

Bu çalışmada okul ortamında ve sınıf ortamında karşılaşılan zorbalık sıklıkları, okulda ne tür zorba davranışlarla karşılaşıldığı, öğrencilerin hangi durumlarda zorba davranışlar yaptıkları, zorbalığa uğrayan öğrencilerin neler yaptıkları, zorbalığa tanık olan öğrencilerin neler yaptıkları, zorbalık karşısında öğretmenlerin neler yaptıkları, zorba davranışların nedenlerinin neler olduğu, zorbalık yapan çocukların özellikleryle ilgili öğretmen görüşlerinin incelenmesi amaçlanmıştır. Bunlara ilaveten, öğretmenlerin zorbalığı önlemek için neler yapılması gerektiğine ve zorbalıkla başetme konusunda nasıl yardım temin ettiklerine ilişkin görüşlerinin incelenmesi de amaçlanmıştır. $\mathrm{Bu}$ araştırmada söz konusu görüşler ilkokul ve ortaokulda görev yapan 32 öğretmenin anket formundaki 11 soruya verdikleri cevaplardan oluşmaktadir.

Bu araştırmanın sonuçları 32 öğretmenden 28 öğretmenin okul ortamında, 29 öğretmenin ise sınıf ortamında zorbalık davranışlarıyla karşılaştıklarını göstermektedir. Bu bulgu araştırmaya katılan ilkokul ve ortakul öğret- 
menlerinin çoğunluğunun okullarında ve sınıflarında zorba davranışlarla karşılaştıkları ve okullarında ve sınfflarında akran zorbalığının yaygın olduğu şeklinde yorumlanabilir. Bu bulgu akran zorbalığının okullarda hem yaygın hem de önemli sorun olduğuna ilişkin önceki araştırma bulgularını desteklemektedir. Örneğin ülkemizde Pişkin (2010) çalışmasında 1154 ilköğretim okulu öğrencisinin \%34'ünün fiziksel zorbalığa, \% 29'unun sözel zorbalığa, \% 21'inin izolasyon, \% 11'inin eşyalarına zarar verme türünde zorbalığa uğradıklarını saptamıştır. Benzer şekilde Pişkin (2006) çalışmasında da okula giden her üç öğrenciden bir öğrencinin bu zorbalığa maruz kaldığını, Kartal ve Bilgin (2008) ise öğrencilerin \%41'inin sürekli olarak zorbalık olaylarına maruz kaldıklarını rapor etmişlerdir. Yurt dışında yapılan çalışmalarda da benzeri bulgularla karşılaşılmaktadır. Wang, Iannotti ve Nansel (2009), 7508 öğrenci üzerinde yaptıkları çalışmada, öğrencilerin \%20.8'inin fiziksel, \%53.6'sının sözel, \%13.6 siber zorbalığa maruz kaldığını tespit etmişlerdir. Bu sunulan araştırmanın ve yukarıda özetlenen ülkemizde ve yurt dışında yapılan araştırmaların sonuçları genel olarak değerlendirildiğinde akran zorbalığının okullarda yaygın olduğunu ve okulların akran zorbalığını önlemeye yönelik politikaları geliştirme açısından yoksun olduğunu düşündürmektedir. Nitekim bu düşünce Atış Akyol vd.'nin (2018) akran zorbalığına ilişkin öğretmen görüşlerini nitel araştırma yöntemiyle inceledikleri araştırmalarında rapor ettikleri; birçok okulda akran zorbalığ1nı önlemeye ilişkin özel bir politikanın olmadığına ilişkin bulgularını desteklemektedir.

$\mathrm{Bu}$ araştırmaya katılan öğretmenler ilkokul ve ortaokullarda görev yapmaktadır. Bu öğretmenler okulda karşılaştıkları zorbalık türlerini sırayla en çoktan aza doğru fiziksel zorbalık, sözel zorbalık, dışlama, taciz, eşyalarını izinsiz kullanma, siber zorbalık, paralarını zorla alma ve kantinden zorla bir şeyler aldırma olarak ifade etmişlerdir. Bu bulgu, Çubukçu ve Dönmez (2012), Gültekin Akduman (2010), Gültekin Akduman (2012) ve Özkan ve Çifci (2010) tarafından yapılan çalışmalarda da ilk ve orta okullarda görülen en yaygın zorbalık türünün fiziksel ve sözel zorbalık olduğu bulgularını desteklemektedir. Gerek bu araştırmanın sonuçları gerek ise yukarıda kısaca özetlenen araştırmaların sonuçları genel olarak ilk okuldan orta okula doğru gidildikçe ya da yaş ilerledikçe fiziksel zorbalığın yerini sözel zorbalığın aldığı şeklinde yorumlanabilir. Bu yorumu Gülten Akduman'ın (2010), 7-8 yaş çocuklarında açık saldırı yani fiziksel şiddet göstermek, diğer yaş 
çocuklarına oranla daha yüksek olduğu, yaşla beraber fiziksel saldırganlığın azaldığ1 ve konuşma becerilerinin gelişmesi ile beraber sözel saldırıların arttı̆̆nna ilişkin görüşlerini desteklemektedir.

Hangi durumlarda zorbalık davranışlarının yapıldığı ile ilgili soruya araştırmaya katılan öğretmenler sırayla öğrencilerin; oyun esnasında, aynı fikirde olmadıklarında, dikkat çekmek istediklerinde, başarılı olan öğrenciyi kıskandıklarında, istekleri yapılmadığında, lider olmak istediklerinde, kendilerini ifade edemediklerinde, öfkelendiklerinde, istemedikleri bir şeyi yapmaya zorlandıklarında ve arkadaşlık ilişkileri bozulduğunda cevaplarını vermişlerdir. Bu bulgular ülkemizde Yalçıntaş Sezgin'in (2018) okullardaki zorbalığı öğretmen görüşlerine göre incelediği araştırmasında belirlediği, öğrencilerin en çok serbest zaman etkinlikleri yaparken zorbalık yaptıkları bulgusunu desteklemektedir. Ülkemizde ve yurt dışında zorbalıkla ilgili çeşitli araştırmalarda da okullarda çocukların oyun alanları olabilecek okul bahçesi, koridorlar, vb yerlerin akran zorbalığının en sık yapıldığı yerler olduğu belirtilmektedir (Baldry ve Farrington, 1999; Bidwell, 1997; Bilgin, 2007; Fekkes, Pijpers ve Verloove-Vanhorick, 2005; Olweus, 1993; Whitney ve Smith, 1993; Yurtal ve Cenkseven, 2006). Kısacası bu araştırmanın sonuçları da önceki araştırmalarda da belirlendiği gibi çocukların okul ortamında zorba davranışı en çok oyun oynarken yaptıkları söylenebilir. Bu araştırmada ilk ve orta okul öğrencilerinin zorba davranışları sırasıyla aynı fikirde olmadıklarında, dikkat çekmek istediklerinde, başarılı olan öğrenciyi kıskandıklarında, istekleri yapılmadığında, lider olmak istediklerinde, kendilerini ifade edemediklerinde, öfkelendiklerinde, istemedikleri bir şeyi yapmaya zorlandıklarında ve arkadaşlık ilişkileri bozulduğunda yapmakta oldukları belirlenmiştir. Sırasıyla ifade edilen bu davranışların ilkokul ve ortaokul dönemlerindeki çocukların içinde bulundukları döneme ilişkin kazanmaları gereken bir takım sosyal duygusal öğrenme becerilerini yeterince geliştirememiş olduklarını düşündürmektedir. Çünkü kişilerarası ilişkilerde, duygusal-davranışsal alanlarda ve okulda karşılaşılan problemleri, kişilerin daha çok sosyal becerilerindeki yetersizliğin bir göstergesi olabilmektedir (Avcıoğlu, 2005; Segrin, 2001). Nitekim zorbalıkla ilgili önceki araştırmalarda öğrencilerin okul kurallarına uymamaları, saldırgan davranmaları ve şiddete başvurmalarının yanı sıra kişilerarası ilişkilerde de başarılı olamadıkları (Olweus, 2005) ve problem çözme becerilerinin düşük, dışa yöneltilmiş öfke düzeylerinin yüksek olduğu (Atik ve Kemer, 2008) bulunmuştur. 
Bunlara ilaveten çeşitli araştırmalarda zorba öğrencilerin ikili ilişkilerde sorunlar yaşadıklarını ve sosyal beceri düzeylerinin düşük olduğu bulunmuştur (Champion, Vernberg ve Shipman, 2003; Fox ve Boulton, 2005; Hilooğlu ve Cenkseven-Önder, 2010; Jenkins, Demaray, Fredrick ve Summers, 2016; Kaukianien vd., 2002).

$\mathrm{Bu}$ araştırmaya katılan öğretmenler, zorbalığa maruz kalan öğrencilerin sırasıyla; öğretmenlerine şikâyette bulunduklarını, sessiz kaldıklarını, zorbaca karşllık verdiklerini, ailesine şikâyet ettiklerini, üzüntü/ağlama şeklinde tepki verdiklerini, arkadaş gruplarına söylediklerini, okuldan soğuduklarını, okul idaresine şikâyet ettiklerini ve başka birine zorbalık yaptıklarını ifade etmişlerdir. Bu araştırmanın bulguları önceki bazı araştırmaların sonuçların desteklemektedir. Örneğin bu araştırmada bulunduğu gibi Gökler (2007) de öğrencilerin zorbalığa uğradıklarında bunu daha çok sınıf öğretmenlerine, sonra arkadaşlarına daha sonra anne babalarına söylediklerini ve kendileriyle en çok ilgilenen kişilerin sinıf öğretmenleri olduğunu belirtmişlerdir. Benzer şekilde Bilgin (2007), ilkokul ve ortaokul öğrencilerinin zorbalığa verdikleri tepkiler arasında ailesinden ve okuldaki bir yetişkinden yardım almanın ilk iki sırada yer aldığını rapor etmiştir. Ancak Bilgin (2007) bu yardımı aldığını söyleyen öğrencilerin yanında sessiz/tepkisiz kaldığını belirten ve "Ben de kötü şeyler söyledim, alay ettim veya lakap taktım" cevabını veren öğrenci sayılarının olduğunu da bulmuştur. Özkan ve Çifci (2010) zorbalığa maruz kalan çocukların büyük bir çoğunluğunun zorbalık yaşadıklarında bunu öğretmenlerine, yarısından fazlasının anne-babalarına, beşte birinin okuldaki bir yetişkine söylediklerini belirlemişlerdir. Kartal ve Bilgin'in (2009) araştırmalarında öğrenciler zorbalığa uğradıklarında bu durumu önce arkadaşlarına anlattıklarını, öğretmenlerinin de tanık oldukları zorba davranışı okuldaki bir yetişkinle paylaştıkların belirlemişlerdir. $\mathrm{Bu}$ sunulan araştırmanın ve önceki benzer amaçla yapılan arştırma sonuçları genel olarak değerlendirildiğinde; zorbalığa maruz kalan öğrencilerin okulda yardım için başvurdukları ilk kaynağın öğretmenler olduğu dikkati çekmektedir. Bu bağlamda okulda zorba davranışları önlemede ve zorba davranışlarla başa çıabilmede öğretmenlerin çok önemli rol ve fonksiyonlarının olduğu söylenebilir.

Okullarda önemli bir diğer grup öğrenci de vardır ki bu öğrenciler ne zorbalığa maruz kalan, ne de zorbalık yapan öğrencilerdir. Bu gruptaki öğrenciler akranlarının zorbalığa uğradığını gören, zorbalıktan etkilenen 
ancak çoğunlukla gözden kaçırılan zorbalığa seyirci/tanık konumunda olan çocuklardır. Bu sunulan araştırmada, araştırmaya katılan öğretmenler, zorbalığa tanık olan öğrencilerin sessiz kaldıklarını, zorbalığı önlemeye çalıştıklarını, öğretmenlerine şikâyet ettiklerini, zorbalığa katıldıklarını, kurbanı savunduklarını, okul idaresine şikâyet ettiklerini ve zorbayı, kurbanın ailesine şikâyet ettiklerini ifade etmişlerdir. Bu bulgular, önceki benzer amaçla yapılan araştırmaların sonuçlarını desteklemektedir. Örneğin; Trach, Hymel, Waterhouse ve Neale (2010) ilkokul 4.siniftan 11.sinıfa kadar olan 9397 öğrenci üzerinde yaptıkları araştırmada daha alt sınıflardaki zorbalığa tanık olan öğrenciler ile kız öğrencilerin zorbalığa doğrudan müdahale ederek, zorbalığa uğrayan mağdur öğrenciye yardım ederek veya bir yetişkine haber vererek zorbalık karşısında olumlu davranışlar sergiledikleri görülmüştür. Benzer şekilde Rigby ve Johnson (2005), ilk ve ortaokullardaki 200 öğrenciye zorbalık olaylarını içeren video izleterek nasıl tepki vereceklerini araştırmışlardır. Araştırma sonuçları, öğrencilerin mağdura yardım edeceğini ve görmezlikten geleceğini belirtenler olarak eşit sayıda öğrenci içeren iki grupta toplandıklarını göstermiştir. Lynn Hawkins, Pepler ve Craig (2001) zorbalığa tanık olan öğrencilerin saldırgan bir şekilde zorbalığa müdahale ettiğini ve bu müdahalenin de genellikle etkili olduğunu tespit etmişlerdir. Özkan ve Çifci (2010) araştırmalarında zorbalığa tanık olan öğrencilerin yarıdan fazlasının zorbalık yapan çocuğa kendisini nasıl hissettiğini sordukları, yarıya yakınının zorbalığa maruz kalan çocuğun bu sorunu çözebilmesi için fikirler üretmesine yardımcı olduklarını belirlemişlerdir. Zorbalığa tanık olan öğrencilerin üçte biri okuldaki bir yetişkinden yardım aldıklarını, yaklaşık dörtte biri ise zorbalığa uğrayan madur çocuğu kendi oyunlarına aldıklarını, zorba çocuğu durdurmaya çalıştıklarını, zorbalığa uğrayan çocuğun kaçmasına yardım ettiklerini belirlemişlerdir. Bu sunulan araştırmanın ve burada kısaca özetlenen araştırma sonuçları genel olarak değerlendirildiğinde; zorbalığa tanık olan çocukların zorbalık karşısındaki tepkilerinin bazı faktörlerden etkilenebileceği düşünülmektedir. Örneğin zorbalığa müdahale eden çocukların sosyal adalet duygularının daha yüksek olduğu bilinmektedir. Zorbalığa müdahale etmeyen çocuklar da olayın doğrudan kendileriyle ilgili olmadığını ve aşırı bir şiddet olmadığı için çekimser kaldıklarını ifade etmektedirler (Cappadocia, Pepler, Cummings ve Craig, 2012). Bir diğer araştırmada, zorbalığa uğrayan çocuğun zorbalığa tanık olan çocuk tarafından savunulması, savunma için yüksek öz yetkinlik 
ve zorbalığa uğrayan çocukla empati kurabilme ile ilişkili bulunmuştur (Pöyhönen, Juvonen ve Salmivalli, 2010). Üstelik izleyiciler, zorbalığa uğrayan çocuğun savunulması ve buna değer vermenin bir sonucu olarak daha iyi hissedeceğine dair olumlu beklentilere sahiptir (Pöyhönen, Juvonen ve Salmivalli, 2012). Bu sunulan araştırmanın ve önceki araştırmaların sonuçları değerlendirildiğinde; zorbalığa tanık olanların zorbalığa müdahalesi; sosyal adalet duygusu, empati düzeyi, müdahale edebilme öz yetkinliği, olumlu sonuç beklentileri gibi faktörlerden etkilenebilmektedir. Bu araştırmanın sonuçlarından, en çok belirtilen zorbalığa tanık olan davranışının sessizlik/tepkisizlik olması ise kaygı uyandırıcıdır. Zorbalığa tanık olanların zorbalık karşısında tepkileri, zorbaların davranışlarını ödüllendirerek veya pekiştirerek zorbalığa katkıda bulunabilmektedir (Saarento ve Salmivalli, 2015). Zorbaların aynı zamanda, zorbalığa tanık olanların sessiz onayından yararlandıkları bile ileri sürülmektedir (Cowie, 2014). Zorbalığa tanık olanlar, zorbanın bir çocuğu yıldırmasına veya incitmesine yardım ederler. Çünkü bu ürkek çoğunluk ki onlar zorbalığa tanık çocuklardır ve onlar, bazen zorbanın sessiz alkışlayıcıları olabilmektedir (Juvonen, Graham ve Schuster, 2003). Ayrıca zorbalığa tanık olanların bu sessizliği/tepkisizliği, kendilerinin de bir gün zorbalığa maruz kalabileceğiyle ilgili endişe ve korkularında kaynaklaniyor olabilir.

$\mathrm{Bu}$ sunulan araştırmaya katılan öğretmenler, öğrencilerinin zorbalık yaptıkları durumlarla karşılaştıklarında sırasıyla; sözel uyarıda bulunduklarını, aile görüşmesi yaptıklarını, öğrencilerle bireysel görüşme yaptıklarını, zorbayı rehberlik servisine yönlendirdiklerini, zorbaya özür dilettirdiklerini, zorbayı okul idaresine yönlendirdiklerini, sorunu tespit etmeye çalıştıklarını, empatiyi öğrettiklerini, zorbaya kızdıklarını, zorbayı cezalandırdıklarını, uygun rol model olmaya çalıştıklarını, görmezden geldiklerini, doğru davranışı pekiştirdiklerini ve zorbayı sürekli gözlemleyerek takip ettiklerini belirtmişlerdir. Öğretmenlerin zorbalığa en çok sözel uyarı ile müdahale ettikleri ve bunun yanı sıra farklı yöntemler kullandıkları görülmektedir. Bu bulgular daha önce yapılan akran zorbalığı karşısında öğretmen tepkilerini inceleyen araştırma bulgularını desteklemektedir. Örneğin Küçükturan ve Gökler (2014), ortaokul öğrencileri üzerinde yaptıkları araştırmada akran zorbalığına karşı öğretmenlerin baş etme stratejilerini araştırmışlardır. Araştırma sonuçları öğretmenler, öğrencileri zorbalık yaptıklarında sırasıyla en çok göz ardı etme, uyarma/tehdit etme, sözlü ve fiziksel şiddet, inisiyatif 
almamak/aracı kullanmak, durumu adilce çözmeye çalışma stratejilerini kullandıkları bulunmuştur. Yalçıntaş Sezgin (2018) öğretmenlerin sınıf içinde zorbalık davranışları karşısında uyguladıkları stratejilerde, en çok çocuk ile davranışı hakkında konuşmak ve uyarı/tehdit stratejilerini uyguladıkları, bununla birlikte, ailesi ile konuşma ve mahrum bırakma cezası stratejilerini uyguladıkları bulunmuştur. Ayrıca mola koltuğu/paspası uyguladıkları da dikkat çekmektedir. En az uyguladıkları strateji de görmezlikten gelme ile sınıf dışında tutma olduğu tespit edilmiştir. Sadık (2002), okul öncesi öğretmenlerinin istenmeyen davranışlarla baş etmede kullandıkları yöntemleri sözel uyarı, açıklama yapma ve fiziksel yakınlığı kullandıklarını rapor etmiştir. Bu çalışmalara ve araştırma sonucuna paralel olarak öğretmenlerin aileyi de sürece dâhil etme (Kochenderfer-Ladd ve Pelletier, 2008; Tepetaş vd., 2010), çocuğu cezalandırma, çocukla konuşup çocuğun sorunu çözmesine yardımc olma (Tepetaş vd., 2010), öğretmenlerin tepkileri arasındadır. Benzer şekilde Marshall, Varjas, Meyers, Graybill ve Skoczylas (2009), öğretmenlerin öğrencilerle konuşma, zorba çocuğun özür dilemesini isteme, rehberlik servisine yönlendirme ve aile ile konuşma, zorba çocuk ile zorba davranışları hakkında konuşma, kurbanı koruma veya zorbaya cezalandırıc1 yöntemler uyguladıklarını belirlemişlerdir. Bu sunulan araştırma bulguları ve yukarıda özetlenen araştırma bulguları genel olarak değerlendirildiğinde, öğretmenlerin zorbalık karşısındaki çoğunlukla gerekli tepkiyi gösterdikleri söylenebilir. Ancak öğretmenlerin zorbalığı önlemede çatışma çözme, problem çözme ve karar verme gibi yaşam becerilerini geliştirmelerinin faydalı olacağı düşünülmektedir.

$\mathrm{Bu}$ araştırmaya katılan öğretmenler, okulda öğrencilerin zorba davranışlar yapmalarının nedenlerini sırasıyla zorba davranışlara ailesel faktörlerin, çevresel faktörlerin, sosyal medya ve televizyonun, yanlış arkadaş seçiminin, zorbalığa maruz kalmanın, kendini ifade edememenin, güçlü olduğunu ispat etmeye çalı̧̧manın, ilgi çekme isteğinin, ergenliğin etkisinin ve savaştan çıkmış olmanın neden olduğunu ifade etmişlerdir. Okulda öğrencilerin zorba davranışlar yapmalarının nedenlerini arasında ilk sıralarda ailesel ve çevresel faktörlerin etkilerinin belirtilmiş olmasının sebebi, çocuğun içinde büyüdüğü aile ve çevrelerindeki yetişkinleri gözlemleyerek onları model almaları sonucunda öğrendiği zorba davranışları okul ve sınıf ortamında uyguladıklarını düşündürmektedir. Bu sunulan araştırmanın bulguları ve görüşler yurt içinde ve dışında yapılan önceki araştırmaların sonuçlarını 
desteklemektedir. Danacı ve Çetin (2016), zorbalığı aile özellikleri bakımından inceledikleri araştırmada, parçalanmış ailede yaşama, tek çocuk olma, düşük sosyo-ekonomik düzey, anne-baba eğitim düzeyinin düşük olması, kardeş sayısı, şiddete maruz kalma durumu gibi faktörlerin zorbalığa neden olduğunu bulmuşlardır. Benzer şekilde Cenkseven-Önder ve Yurtal (2008) ve Gültekin Akduman (2010) çalışmalarında akran zorbalığının başlıca nedeninin ailevi faktörler olduğunu tespit etmişlerdir. Hoşgörür ve Orhan (2017), okul müdürlerinin görüşlerine göre okulda zorba davranışların nedenlerinin; ailenin çocuğu yetiştirme tarzından, aile içi şiddetten, öğrencinin içinde bulunduğu çevreden, görsel medyadaki şiddet içeren yapımlardan, öğrencinin akademik başarısızlığından kaynaklanabileceğini belirlemişlerdir. Bu sunulan araştırmanın bulguları, yurtdışında zorbalığın nedenlerinin araştırıldığı çeşitli araştırmaların sonuçlarını desteklemektedir. Örneğin Carney ve Merrell (2001), zorba çocukların ebeveynleri üzerinde yaptıkları araştırmada zorba çocukların sert disiplin teknikleryle ve bedensel cezaya maruz bırakılarak yetiştirildiklerini belirlemişlerdir. Akran zorbalığının nedenlerini Asimopoulos, Bibou-Nakou, Hatzipemou, Soumaki ve Tsiantis (2014) psikopatolojik özellikler, ailede yaşanan sorunlar ve ailelerin çocuklarını ihmal etmesi, ebeveynlerin öğretmenlerle işbirliği kurma konusunda ilgisizliği, okuldaki bir psiko-sosyal destek ağı eksikliği, eğitim sisteminin zayıf yönleri şeklinde ifade etmektedirler. Yurtdışında yapılan başka bir araştırmada da ailenin duygusal yapısı, ailenin sosyo-ekonomik durumu ve göç geçmişi gibi çeşitli ailesel özelliklerin zorbalığın veya kurban olmanın oluşumunda etkili oldukları bulunmuştur (Perren, Stadelmann ve Von Klitzing, 2009). Kısacası bu sunulan araştırmanın ve önceki araştırmaların sonuçları, çocukların yetiştikleri aile ve çevresinin çocukların zorba davranışları öğrendikleri birincil kaynaklar olduklarını göstermektedir. Bir başka anlatımla çocuklar hangi tür aile, kültür veya eğitim sistemi içinde yetişirlerse yetişsinler, çocukların zorba davranışları öğrenmesinde aile ve çevresinin ilk sırada yer aldığı söylenebilir.

Araştırmaya katılan öğretmenler zorbalık davranışını sırasıyla aile sorunları olan, fiziksel olarak iri, akademik başarısı düşük, kendini doğru ifade edemeyenlerin, cinsiyeti erkek olanların, maddi sorun yaşayanların, öz güven yüksek, saldırgan, savaş tanığı ve maddi durumu iyi olan çocukların yaptıklarını ifade etmişlerdir. Bu bulgular önceki araştırmaların bulgularını desteklemektedir. Yalçıntaş Sezgin' in (2018) araştırmasında da öğretmenler 
fiziksel olarak yaşıtlardan büyük (iri/kilolu) olan çocukların daha çok zorbalık davranışlarında bulunduklarını belirtmişlerdir. Atik ve Kemer (2008), ilköğretim ikinci kademe/ortaokul öğrencileri örnekleminde çalıştıkları araştırmada zorba çocukların yüksek fiziksel öz yeterliğe sahip oldukların belirlemişlerdir. Monks, Palermiti, Ortega ve Costabile (2011) çalışmasında, hem öğretmenler hem de öğrenciler zorbalık davranışları gösteren çocukların fiziksel olarak güçlü çocuklar olduklarını belirtmişlerdir. Zorbalık yapan çocukların ve ergenlerin genellikle fiziksel ve duygusal olarak daha güçlü oldukları, diğer öğrencileri yönetmeyi sevdikleri, başkaları üzerinde egemenlik kurmayı ve güçlü olmayı istedikleri ve diğerlerinin duygularına karşı duyarsız oldukları saptanmıştır (Pearce ve Thompson, 1998; Ural ve Özteke, 2007). Jansen vd., (2012) düşük sosyo ekonomik düzeye sahip ailelerden gelen çocukların, zorbalık yapma ve kurban olma açısından daha fazla risk altında olduklarına dikkat çekmektedir. Irene ve Mona'nın (2003) zorbalık yapan ve yapmayan erkek ve kız çocuklarını karşılaştırdıkları araştırmalarında, zorba çocukların aile üyeleriyle çok daha olumsuz ilişkiye sahip olduğu gözlenmiştir. Bazı çocuklar şiddet uygulayan ebeveynini model alıp arkadaşlarına şiddet uygulayabiliyorken bazıları ise şiddet gören ebeveyni gibi içine kapanmakta ve okulda da zorbalık kurbanı olabilmektedirler (Uysal ve Dinçer, 2012). Benzer şekilde Perren vd. (2009), zorbalık davranışları gösteren çocuklar; hiperaktif, dürtüsel ve akran reddi ile karşılaşmış, akademik zorluk yaşayan ve travmaya maruz kalan çocuklar olarak da tanımlanmaktadırlar. Bu sunulan araştırmanın ve yukarda kısaca özetlenen araştırmaların sonuçları zorbaca davranışlar sergileyen çocukların birçok özellikleri olduğunu göstermektedir. Zorba öğrenciler için tüm araştırmalarda ilk sırada yer verilen özelliklerinde, zorba öğrenciler genellikle fiziksel olarak güçlü ve yüksek enerjiye sahip çocuklar olarak tanımlanmaktadır. Bu çocuklar, saldırganca davranışlar sergilemekten ve çatışmalara girmekten hoşlanmaktadırlar. Ayrıca zorba çocuklar, saldırganca davranışlarının akranlarınca izlenmesinden de gurur duymaktadırlar (Olweus, 1993). Zorba çocuklar diğerlerini baskı altına almaktan haz duymaktadırlar. Bu çocuklar yeni bir akran grubuna girdiklerinde, o grup içinde lider olabilmek için saldırganca davranışları düzenli ve sürekli olarak sergilemektedirler. Zorba çocuklar, saldırganlığı girdiği yeni grupta kendi gücünü kabul ettirmek için kullanmaktadırlar ve bu amaca ulaşmak için de fiziksel olarak 
kendilerinden daha zayıf, sosyal olarak yetersiz ve yalnız çocukları hedef olarak seçmektedirler (Olweus, 1994).

$\mathrm{Bu}$ araştırmaya katılılan öğretmenler, okullarda zorbalığı önlemek için; öğrencilerin ailelerine aile eğitimi verilmesini, ailelerle işbirliği yapılmasını, öğrencilere empati eğitimi verilmesini, psiko-sosyal müdahale yapılmasını, problem çözme becerisi kazandırmayı, başarıyı tattırmayı, disiplin cezasını önlemeye yönelik eğitimler verilmesini önermektedirler. Bunlara ilaveten öğrencilere uygun rol model olacak çalışmalar ile aile danışmanlığının gerekli olduğunu önermektedirler. Zorbalıkla ilgili araştırma sonuçları, zorbalığı önlemek için, zorbalık yapan çocuk ve çevresine bazı becerileri (problem çözme, etkili iletişim kurabilme gibi) kazandırmayı amaçlayan veya çocuğun çevresindekilere zorbalık ve zorbalığı önleye yönelik seminer ve konferanslar düzenlenmesi önerildiği ve çocuğun çevresi ile işbirliğine vurgu yapıldığı görülmektedir. McWhirter, McWhirter, McWhirter ve McWhirter (2004), zorbalıkla bağlantılı gösterilen anti-sosyal davranışların oluşumunu açıklayan bir model geliştirmişlerdir. Bu modele göre toplum, topluluk ve çocuğun mikro sistemi, anti sosyal davranışın önemli belirleyicileri olarak ifade edilmektedir. Çocuklar gelişim sürecinde, birincil sosyal çevrenin aile ve okul olmasına rağmen, çocuklar mahallesindeki akranları ve yetişkinlerle de etkileşim içerisindedir. Bebeklik ve ilk çocukluk dönemindeki tutarsız disiplin, yetişkinlerin şiddet davranışlarını model alma çocuğun da şiddet ve zorbalık gibi anti-sosyal davranıslar geliştirmesini kolaylaştırmaktadır. Öğrencinin çevresiyle etkileşiminin zorba davranışların gelişimine etkisi düşünüldüğünde başta çocuklar ve ailelerinin zorbalık konusunda eğitilmesi ve bilinçlendirilmesinin önemli olduğu söylenebilir. Ayrıca Çubukçu ve Dönmez'in (2012) yaptığı araştırma sonucuna göre, ilköğretim okul yöneticilerinin okullarda zorbalığın önlenmesi için; anne-baba eğitiminin, öğrenci eğitiminin ve öğretmen eğitiminin gerekli olduğunu belirtmesi, araştırma sonuçlarını desteklemektedir.

Araştırmaya katılan öğretmenler, zorbalıkla başa çıkmak için ihtiyaç duydukları yardımı sırasıylas; rehberlik servislerinden (psikolojik danışmanlardan), okul idaresinden, ailelerden, diğer öğretmenlerden ve psikologlardan aldıklarını belirtmişlerdir. Öğretmenlerin zorbalıkla başa çıkmak için ilk sırada okul rehberlik servislerinden yardım istemeleri beklenen, üstelik istenilen bir görüştür. Araştırmaya katılan öğretmenlerin bu cevabı onların zorbalık gibi uzmanlık gerekteren bir yardımı psikolojik danışman- 
lardan istemeleri bir bakıma öğretmenlerin okul rehberlik servislerininin işlevlerini, yani okul psikolojik danışmanlarının okuldaki rol ve fonksiyonlarını bildiklerine işaret etmektedir. Ayrıca öğretmenlerin bu cevaplarına dayanarak öğretmenlerin görevlerini yaparken öğrencilerle sorun yaşadıklarında ya da öğerenciler birbirleriyle sorun yaşadıklarında bu sorunla başa çıkabilmelerinde okul reberlik servislerindeki psikolojik danışmanların rol ve görevlerine önem verdiklerini de düşündürmektedir. Bu araştırmanın bu bulgusunun önceki araştırmaların bulgularını desteklediği görülmektedir. Örneğin Atış Akyol vd. (2018) öğretmenlerin zorbalık durumunda en fazla aileler ve rehberlik servisleriyle işbirliği yaptığını tespit etmişlerdir. Akar Çevlik (2013) tarafından yapılan araştırmada zorbalık durumunda öğretmenlerin zorbalık yapan öğrenciyi rehberlik servisine, okul idaresi ya da ailesine bildirdiğini tespit etmişlerdir. Ayrıca bu sunulan araştırma bulguları Kaya, Macit ve Siyez'in (2012), bir ilköğretim okulu rehberlik ve psikolojik danışma servisine yapılan başvuruları inceledikleri araştırmada; hırçınlık, vurma, saldırganlık ve arkadaş çatışması nedeniyle okul rehberlik servisine yapılan başvuruların her sınıf düzeyinde olduğu bulgusunu desteklemektedir. Bu sunulan araştırmanın bulguları ve yukarıda özetlenen araştırma bulguları genel olarak değerlendirildiğinde, okullarda zorbalığ için rehberlik servisleri başta olmak üzere ilgililerle iş birliği yapmanın büyük öneme sahip olduğu söylenebilir.

$\mathrm{Bu}$ araştırmanın bulguları, okullarda karşılaşılan akran zorbalığıyla ilgili literatüre, teoriye ve pratiğe yönelik önemli katkılar sunmaktadır. Bununla birlikte temel nitel betimsel desenle çalışılan bu araştırmanın bazı sınırlılıkları vardır. İlki, bu araştırmanın katılımcıları ilkokul ve ortaokullarda görev yapan öğretmenlerdir. Araştırmada öğretmenlerin görüşleri ilkokul ve ortaokul düzeyine göre ayırılarak değerlendirilmemiştir. Benzer amaçla gelecekte nitel ve nicel yöntemlerle çalışılacak araştırmalarda okul zorbalığının sınıf düzeyine, ilkokul ve ortaokul dönemlerine veya yaşa göre farklılaşıp farklılaşmadığı araştırılabilir. İkinci sınırlılık, bu araştırmanın verileri anket kullanılarak toplanmıştır. Anket tekniği, derinlemesine veri toplamak için yeterli olmayabilir. Gelecek araştırmalarda yarı yapılandırılmış görüşme tekniği kullanılarak katılımclardan konu ile ilgili daha detaylı bilgiler toplanabilir. Üçüncü sınırlılık ise, araştırma verilerinin sadece Ankara ve Kahramanmaraş illerinde görev yapan ilkokul ve ortaokul öğretmenleriden toplanmasıdır. Gelecekte yapılacak araştırmalarda çeşitli il veya ilçelerde 
çalışan öğretmenlerden oluşacak örneklemler üzerinde çalışılması önerilebilir. $\mathrm{Bu}$ araştırmanın sonuçlarından öncelikle araştırmacılar akran zorbalığ konusunda gelecekte yapacakları teorik ve uygulamalı araştırmalar için yararlanabilirler. Ayrıca bu araştırmanın sonuçlarından akran zorbalığını önlemeye yönelik eğitim politikaları oluşturulurken, eylem planları geliştirilirken ve pratiğe yönelik çalışmalar planlanırken yararlanılması önerilmektedir. Ebeveynler için aile eğitim programları düzenlenerek akran zorbalığ ve önlenmesi konusunda bilinçlendirme sağlanabilir. Okullarda öğrencilerin sosyal duygusal öğrenme becerilerini geliştirmeye yönelik etkinlikler yapılarak çocukların sosyal beceri düzeylerinin arttırılması sağlanabilir. Öğrencilere okullarda akran zorbalığı ile ilgili psiko-eğitim programları uygulanarak konu hakkında bilinçlenmeleri sağlanabilir. Özellikle zorbalığa tanık olan öğrenciler için de zorbalığı önleyici grup rehberliği ve psikoeğitim programları düzenlenmelidir. Okul psikolojik danışmanları 'Öğretmenlerin okul zorbalığını önlemede rol ve fonksiyonları' konulu seminer çalışmaları yapabilirler. Öğretmenlere yönelik zorbalığın tür ve özellikleri konulu hizmet içi eğitim çalışmaları düzenlenerek konu hakkındaki hassasiyetleri arttırılabilir. Öğretmenlerin hizmet içi eğitim çalışmalarında okul zorbalığını önlemelerine yardımcı olmak için çatışma çözme, problem çözme ve karar verme gibi yaşam becerilerini geliştirmelerine yardım edilebilir. 


\title{
EXTENDED ABSTRACT
}

\section{Peer Bullying in Schools: A Qualitative Study According to Teachers Views}

\author{
Ersoy Çarkıt-Feride Bacanlı \\ Nevşehir Hacı Bektaş Veli University - Gazi Üniversity
}

School bullying is the most common type of school violence. Bullying is usually defined as repeated behaviour which is intended to hurt someone either emotionally or physically, and is often aimed at certain people because of their race, religion, gender or sexual orientation or any other aspect such as appearance or disability. Scientific reports have shown that bullying can lead to serious mental and physical problems (Morita, 1985). School bullying has gained a universal interest among researchers, the media, school administrators and parents who are interested in the psychological health and safety of the child (Bosworth, Espelage, and Simon, 1999; Ma, 2001; Smith and Brian, 2000). Those who witness bullying at school are not only victims and other students, but also teachers and administrators. Hence, it is considered that it is necessary and important to examine the opinions of the teachers and administrators who have witnessed bullying and even the other staff (civil servant, servitor ship) in the school about the bullying. The purpose of this study is to examine in depth the phenomenon of peer bullying, which has occurred in schools, according to the opinions of teachers. Another goal of this study is to determine sources of help which help them deal with bullying in elementary and secondary schools. The results of this study will enable the determination of the opinions of today's teacher about school bullying. It is thought that the findings can be used in theoretical and practical researches in order to prevent school bullying. It is thought that the findings may also be used in future empirical research on school bullying. In addition, it is thought that it will contribute to the future researches related to teacher and student relations in the school environment.

This research has been carried out with phenomenology design using qualitative research method. The study group is composed of teachers who work in elementary and secondary schools. The study group consists of 32 
teachers who are 26 female and 6 male. 28 participants have bachelors' degrees and 4 participants have post graduate degrees. Questionnaire was developed by researchers to collect data in the research. The final form of the questionnaire has been given in the direction of the expert opinion. While the first part contains the demographic information of the participants, the second part contains, there are open-ended and closed-ended questions which examine teacher views about peer bullying. The purpose of research was explained and questionnaire was applied to teachers who volunteered to participate in the study. The obtained data were analyzed using the content analysis method.

As result of the research, most of the teachers stated that they had peer bullying in their school and class, and that this was mostly physical bullying. Students often bullied while playing games and when they do not agree. It has been found that students who are exposed to the bully mostly complain to the teacher and remain silent. Students who witness the bullying are mostly remain silent. Teachers stated that they warned students when they witnessed bullying. Teachers stated that when they witness bullying, they contact with parents of students who are bully. According to teachers, the underlying cause of bullying is usually related to familial factors. Students who are bullying are usually students who have family problems and are physically large. Teachers stated that families must be trained to prevent bullying and they stated that it is necessary to cooperate with the parents to prevent bullying. Teachers stated that they receive support from the school guidance services to deal with bullying.

As result, peer bullying and verbal bullying are very common in elementary and middle schools. The findings of this study showed that physical bullying and verbal bullying are the most common type of bullying experienced in elementary and middle schools. This finding supports the findings of Özkan and Çifci (2010), Çubukçu and Dönmez (2012), Gültekin Akduman (2010, 2012) and Adalar (2018). Students often bullied while playing games. There are studies in the literature that report children's bullying behaviors are mostly seen during play (Olweus, 1993; Baldry and Farrington 1999; Fekkes, Pijpers and Verloove-Vanhorick, 2005). It has been emphasized by teachers that familial factors are the main cause of bullying, which was frequently reported in similar studies (Danacı and Çetin, 2016; Şahin, Demirağ and Aykaç, 2009; Asimopoulos, Bibou-Nakou, Hatzipemou, Sou- 
maki and Tsiantis, 2014; Hoşgörür and Orhan, 2017). Teachers need often help to deal with bullying. This assistance is most requested from the school guidance service. It is suggested that policies should be established in schools to prevent peer bullying. Family education programs can be organized for parents to raise awareness of peer bullying and prevention. In elementary and middle schools, activities to improve students' social emotional learning skills can be made. Bullying prevention group guidance and psychoeducation programs should be organized for especially students who have witnessed bullying.

\section{Kaynakça / References}

Akar Çevlik P. (2013). Okul yöneticilerinin ve öğretmenlerin akran zorbalı̆̆ına ilişkin tutumları ve müdahale stratejileri. Yayınlanmamış yüksek lisans tezi. İnönü Üniversitesi, Malatya.

Akca, E. B., Sayımer, İ., Salı, J. B., ve Başak, B. E. (2014). Okulda siber zorbalığın nedenleri, türleri ve medya okuryazarlığı eğitiminin önleyici çalışmalardaki yeri. Elektronik Mesleki Gelişim ve Araştırmalar Dergisi, 2(2), 17-30.

Aksoy, G. (2019). Okullarda yaşanan akran zorbahı̆̆ının nedenlerine ve müdahale yöntemlerine ilişkin okul yöneticileri ve öğretmenlerin görüşleri. (Yayınlanmamış Yüksek Lisans Tezi). Marmara Üniversitesi, İstanbul.

Asimopoulos, C., Bibou-Nakou, I., Hatzipemou, T., Soumaki, E., ve Tsiantis, J. (2014). An investigation into students' and teachers' knowledge, attitudes and beliefs about bullying in Greek primary schools. International Journal of Mental Health Promotion, 16(1), 42-52.

Atış Akyol, N., Yıldız, C., ve Akman, B. (2018). Öğretmenlerin akran zorbalığına ilişkin görüşleri ve zorbalıkla baş etme stratejileri. Hacettepe Üniversitesi Ĕ̆itim Fakültesi Dergisi, 33(2), 439-459.

Atik, G. (2006). The role of locus of control, self-esteem, parenting style, loneliness, and academic achievement in predicting bullying among middle school students. Yayınlanmamış yüksek lisans tezi. Orta Doğu Teknik Üniversitesi, Ankara.

Atik, G., ve Kemer, G. (2008). İlköğretim ikinci kademe öğrencileri arasındaki zorbalığ1 yordamada problem çözme becerisi, sürekli öfke-öfke ifade tarzları ve fiziksel öz yeterliğin rolü. Dokuz Eylül Üniversitesi Buca Ĕ̆itim Fakültesi Dergisi, 23, 198-206. 
Avcioğlu, H. (2005). Etkinliklerle sosyal beceri öğretimi. Ankara: Kök Yayıncilık.

Ayas, T., ve Pişkin, M. (2011). Lise öğrencileri arasındaki zorbalık olaylarının cinsiyet, sınıf düzeyi ve okul türü bakımından incelenmesi. Illköğretim Online, 10(2), 550-568.

Baldry, A. C., ve Farrington, D. P. (1999). Types of bullying among Italian school children. Journal of Adolescence, 22, 423-426.

Bedel, A., ve Güler, G. (2020). Ortaokul öğrencilerinde zorbaliği ve saldirganliği açiklamada başa çikma stratejilerinin rolü. Elektronik Sosyal Bilimler Dergisi, 19(73), 105-121.

Bender, D., ve Lösel, F. (2011). Bullying at school as a predictor of delinquency, violence and other anti-social behaviour in adulthood. Criminal Behaviour and Mental Health, 21(2), 99-106.

Bidwell, N. (1997, May). The nature and prevalence of bullying in elementary schools. (SSTA Research Center Report No. 97-06). Regina, Saskatchewan: Saskatchewan School Trustees Association.

Bilgin, A. (2007). Yatılı ve gündüzlü ilköğretim okulu öğrencilerinin zorbalığa ilişkin görüşleri. Ege Ĕ̆itim Dergisi, 8(1), 1-18.

Bosworth, K., Espelage, D. L. ve Simon, T. R. (1999). Factors associated with bullying behavior in middle school students. The Journal of Early Adolescence, 19(3), 341-362.

Boulton, M. J., ve Smith, P. K. (1994). Bully/victim problems in middleschoolchildren: stability, self-perceived competence, peer rejection and peer acceptance. British Journal Developmental Psychoogyl, 12, 315329.

Boulton, M. J., ve Underwood, K. (1992). Bully/victim problems among middleschool children. British Journal Education Psychology, 62, 73-87.

Bozkurt, S., Akbıyık, A., Yüzük, S., Gördeles Beşer, N., ve Sağkal, T. (2011). Bir yatılı bölge okulunda akran istismarı ve farkındalık eğitiminin etkisi. Anadolu Hemşirelik ve Sağlık Bilimleri Dergisi, 14(4), 1-9.

Brown, E. C., Low, S., Smith, B. H., ve Haggerty, K. P. (2011). Outcomes from a school-randomized controlled trial of STEPS to RESPECT: A bullying prevention program. School Psychology Review, 40(3), 423-443.

Büyüköztürk, Ş., Çakmak, E. K., Akgün, Ö. E., Karadeniz, Ş., ve Demirel, F. (2013). Bilimsel araştırma yöntemleri (15. Bask1). Ankara: Pegem Akademi.

Byrne, B. (1994). Bullies and victims in a school setting with reference to some Dublin schools. Irternational Journal of Psychology, 15, 574-586. 
Cappadocia, M. C., Pepler, D., Cummings, J. G., ve Craig, W. (2012). Individual motivations and characteristics associated with bystander intervention during bullying episodes among children and youth. Canadian Journal of School Psychology, 27(3), 201-216.

Carney, A. G., ve Merrell, K. W. (2001). Bullying in schools: perspectives on perspectives on understanding and preventing an international problem. School Psychology International, 22(3), 364-382.

Champion, K., Vernberg, E., ve Shipman, K. (2003). Nonbullying victims of bullies: Aggression, social skills, and friendship characteristics. Applied Developmental Psychology, 24, 535-551.

Cenkseven-Önder, F. ve Yurtal, F. (2008). Zorba, kurban ve olumlu özellikler taşıyan ergenlerin aile özelliklerinin incelenmesi. Educational Sciences: Theory \& Practice, 8(3), 805-832.

Chatters, S. J., ve Zalaquett, C. P. (2018). Bullying prevention and prejudice reduction: assessing the outcome of an integrative training program. The Journal of Individual Psychology, 74(1), 20-37.

Cole, D. A., Sinclair-McBride, K. R., Zelkowitz, R., Bilsk, S. A., Roeder, K., ve Spinelli, T. (2016). Peer victimization and harsh parenting predict cognitive diatheses for depression in children and adolescents. Journal of Clinical Child \& Adolescent Psychology, 45, 668-680.

Cowie, H. (2014). Understanding the role of bystanders and peer support in school bullying. International Journal of Emotional Education, 6(1), 26-32.

Çelik, S., Toraman, S. Ö., ve Çelik, K. (2018). Öğrenci başarısının derse katılım ve öğretmen yakınlığıyla ilişkisi. Kastamonu Üniversitesi Kastamonu Ĕ̆itim Dergisi, 26(1), 209-217.

Çubukçu, Z., ve Dönmez, A. (2012). İlköğretim okul yöneticilerinin şiddet türlerine yönelik görüşleri ve şiddetle başa çıkma yöntemleri. Kuram ve Uygulamada Ĕ̈itim Yönetimi Dergisi, 18(1), 37-64.

Dake, J. A., Price, J. H., Telljohann, S. K., ve Funk, J. B. (2003). Teacher perceptions and practices regarding school bullying prevention. Journal of School Health, 73(9), 347-355.

Dake, J. A., Price, J. H., ve Telljohann, S. (2003). The nature and extent of bullying at school. Journal of School Health, 73(5), 173-180.

Danacı, M. Ö. ve Çetin, Z. (2016). Erken çocukluk döneminde görülen okul zorbalığı davranış eğilimlerinin çocukların kişisel/sosyal-dil-motor gelişimleri ile olan ilişkisi. Hacettepe Üniversitesi Sağlık Bilimleri Fakültesi Dergisi, 3(2).53-72. 
Demirtaş, Z. (2010). Okul kültürü ile öğrenci başarısı arasındaki ilişki. Eğitim ve Bilim, 35(158), 3-13.

Due, P., Holstein, B. E., Lynch, J., Diderichsen, F., Gabhain, S. N., Scheidt, P., ve Currie, C. (2005). Bullying and symptoms among school-aged children: international comparative cross sectional study in 28 countries. European Journal of Public Health, 15(2), 128-132.

Espelage, D. L. (2018). Understanding the complexity of school bully involvement. The Chautauqua Journal, 2(20), 1-24.

Fekkes, M., Pijpers, F. M. I., ve Verloove-Vanhorick, S. P. (2005). Bullying: Who does what, when and where? Involvement of children, teachers and parents in bullying behavior. Health Education Research, 20(1), 81-91.

Forero, R., McLellan, L., Rissel, C., ve Bauman, A. (1999). Bullying behaviour and psychosocial health among school students in New South Wales, Australia: Cross sectional survey. The British Medical Journal, 319(7206), 344-348.

Fox, C. L., ve Boulton, M. J. (2005). The social skills problems of victims of bullying: Self, peer and teacher perceptions. British Journal of Edicational Psychology, 75, 313-328.

Gökkaya, F., ve Tekinsav Sütcü, S. (2018a). İlköğretim öğrencilerinde zorbalık eğilimini azaltmaya yönelik bilişsel davranışçı bir müdahale programının geliştirilmesi ve etkililiğinin değerlendirilmesi. Eğitim ve Bilim, 43(193), 91-108.

Gökkaya, F., ve Tekinsav Sütcü, S. (2018b). Akran zorbalığının ortaokul öğrencileri arasındaki yaygınlığının incelenmesi. Hacettepe Üniversitesi Eğitim Fakültesi Dergisi. Advance online publication. doi: 10.16986/HUJE.2018042225

Gökler, R. (2007). İlköğretim öğrencilerinde akran zorbalığının bazı değişkenler açısından incelenmesi. (Yayınlanmamış doktora tezi). Ankara Üniversitesi, Ankara.

Gökler, R. (2009). Okullarda akran zorbalığı. Uluslararası İnsan Bilimleri Dergisi 6(2), 511-537.

Gurbetoğlu, A., ve Tomakin, E. (2011). Sevilen ve sevilmeyen öğretmen davranışlarına ilişkin öğrenci görüşlerinin incelenmesi. Ahi Evran Üniversitesi Eğitim Fakültesi Dergisi, 1(12), 261-276.

Gür, N., Eray, Ş., Makinecioğlu, I., Sığırlı, D., ve Vural, A. P. (2020). Akran zorbalığı ile aile duygu dışa vurumu ve psikopatoloji arasındaki ilişki. Anadolu Psikiyatri Dergisi, 21(1), 77-86. 
Gültekin Akduman, G. (2010). 7-8 yaş grubu çocuklarda akran istismarı ve kendi çözüm önerileri. Kuramsal Ĕ̆itimbilim, 3(2), 13-26.

Gültekin Akduman, G. (2012).Okul öncesi dönemde akran zorbalığının incelenmesi. Toplum ve Sosyal Hizmet, 23(1), 121-137.

Greenbaum, S., Turner, B., ve Stephens, R. D. (1988). Set straight on bullies. Los Angeles: Pepperdine University Press.

Hazler, R. J., Hoover, J. H., ve Oliver, R. (1992). What kids say about bullying. The Executive Educators, 14, 20-22.

Hilooğlu, S., ve Cenkseven-Önder, F. (2010). İlköğretim ikinci kademe öğrencilerinde zorbalığ 1 yordamada sosyal beceri ve yaşam doyumunun rolü. İlköğretim Online, 9(3), 1159-1173.

Hilliard, L. J., Batanova, M., ve Bowers, E. P. (2015). A positive youth development approach to bullying: Promoting thriving and reducing problem behaviors. In Promoting Positive Youth Development (pp. 249-272). Springer, Cham.

Horzum, M. B., ve Ayas, T. (2011). Ortaöğretim öğrencilerinin sanal zorba ve mağdur olma düzeylerinin okul türü ve cinsiyet açısından incelenmesi. Journal of Educational Sciences \& Practices, 10(20), 139-159.

Hoşgörür, V., ve Orhan, A. (2017). Okulda zorbalık ve şiddetin nedenleri ve önlenmesinin yönetimi (Muğla merkez ilçe örneği). Bayburt Eğitim Fakültesi Dergisi, 12(24), 859-880.

Irene, C., ve Mona, M. (2003). Personality and family relations of children who bully. Personality and Individual Differences, 35, 559-567.

İnandı, Y., ve Yıldız, S. (2014). Lise okul yöneticilerinin okullarda şiddeti önleme yeterlikleri: Mersin ili örneği. Trakya Üniversitesi Eğitim Fakültesi Dergisi, 4(2), 137-147.

Jacobs, A. K. (2008). Components of evidence-based interventions for bullying and peer victimization. In Handbook of evidence-based therapies for children and adolescents (p. 261-279). Springer, Boston, MA.

Jansen, P. W., Verlinden, M., Dommisse-van Berkel, A., Mieloo, C., van der Ende, J., Veenstra, R., Verhulst, F., C., Janseni, W., ve Tiemeier, H. (2012). Prevalence of bullying and victimization among children in early elementary school: Do family and school neighbourhood socioeconomic status matter?. BMC Public Health, 12(1), 494-503.

Jenkins, L. N., Demaray, M. K., Fredrick, S. S., ve Summers, K. H. (2016). Associations among middle school students' bullying roles and social skills. Journal of School Violence, 15(3), 259-278. 
Jenkins, L.N., ve Nickerson, A.B. (2019). Bystander intervention in bullying: role of social skills and gender. Journal of Early Adolescence, 39(2), 141-166.

Juvonen, J., Graham, S., ve Schuster, M. A. (2003). Bullying among young adolescents: The strong, the weak and the troubled, Pediatrics, 112(6), 1231-1237.

Kaltiala-Heino, R., Rimpelä, M., Rantanen, P., ve Rimpelä, A. (2000). Bullying at school-an indicator of adolescents at risk for mental disorders. Journal of Adolescence, 23(6), 661-674.

Kartal, H., ve Bilgin, A. (2009). İlköğretim okullarında görev yapan öğretmenler ve öğrenim gören öğrencilerin zorbalığa yönelik görüşleri. Türk Ĕ̆gitim Bilimleri Dergisi, 7(3), 539-562.

Kartal, H., ve Bilgin, A. (2012). İlköğretim öğrencilerinin zorbalığın nedenleri ile ilgili algiları. Gaziantep University Journal of Social Sciences, 11(1), 25-48.

Kartal, H. (2009). Öğretmen adaylarının uygulama okullarındaki zorbalıkla ilgili değerlendirmeleri. Gazi Ĕ̆itim Fakültesi Dergisi, 29(1), 141-172.

Kartal, H., ve Bilgin, A. (2008). Bullying in the elementary schools: From the aspects of the students, the teachers and the parents. Ilkögrretim Online, 7(2), 485-495.

Kaukianien, A., Salmivalli, C., Lagerspetz, K., Tamminen, M., Vaures, M., Mäki, H., ve Poskıparta, E. (2002). Learning difficulties, social intelligence, and self-concept: Connections to bully-victim problems. Scandinavian Journal of Psychology, 43, 269-278.

Kaya, A., Macit, Z. B., ve Siyez, D. M. (2012). Bir ilköğretim okulu psikolojik danışma ve rehberlik servisine yapılan başvuruların incelenmesi. Illköğretim Online, 11(4), 1087-1100.

Kim, M. J., Catalano, R. F., Haggerty, K. P., ve Abbott, R. D. (2011). Bullying at elementary school and problem behaviour in young adulthood: A study of bullying, violence and substance use from age 11 to age 21. Criminal Behaviour and Mental Health, 21(2), 136-144.

Kim, Y. S., Leventhal, B. L., Koh, Y. J., Hubbard, A., ve Boyce, W. T. (2006). School bullying and youth violence: causes or consequences of psychopathologic behavior?. Archives of general psychiatry, 63(9), 1035-1041.

Kochenderfer-Ladd, B. J., ve Pelletier, M. E. (2008). Teachers' views and beliefs about bullying: Influences on classroom management strategies and students' coping with peer victimization. Journal of School Psychology, 46, 431-453. 
Kurt Demirbaş, N., ve Öztemel, K. (2019). Zorbalığa seyirci müdahale ölçeği'nin (ZSMÖ) Türkçe uyarlaması: Geçerlik ve güvenirlik çalışması. Türk Psikolojik Danışma ve Rehberlik Dergisi, 9(54), 965-985.

Küçükturan, G., ve Gökler, B. (2014). Investigation of the teachers' coping strategies against peer bullying. European International Journal of Science and Technology, 3(9), 99-114.

Lambert, V., ve Lambert, C. (2012). Qualitative descriptive research: An acceptable design. Pacific Rim International Journal of Nursing Research, 16(4), 255-256.

Lincoln, Y.,ve Guba, E. (1985). Naturalistic inquiry. Beverly Hills, CA: Sage.

Lynn Hawkins, D., Pepler, D. J., ve Craig, W. M. (2001). Naturalistic observations of peer interventions in bullying. Social Development, 10(4), 512-527.

Ma, X. (2001). Bullying and being bullied: To what extent are bullies also victims?. American Educational Research Journal, 38(2), 351-370.

Marshall, M. L., Varjas, K., Meyers, J., Graybill, E. C., ve Skoczylas, R. B. (2009). Teacher responses to bullying: Selfreports from the front line. Journal of School Violence, 8, 136-158.

Menesini, E., Sanchez, V., Fonzi, A., Ortega, R., Costabile, A., ve Lo Feudo, G. (2003). Moral emotions and bullying: A cross-national comparison of differences between bullies, victims and outsiders. Aggressive Behavior: Official Journal of the International Society for Research on Aggression, 29(6), 515-530.

McWhirter, B. T., McWhirter, E. H., McWhirter, J. J., ve McWhirter, R. J. (2007). At-risk youth: A comprehensive response for counsellors, teachers, psychologists, and human services professionals. Belmont, CA: Thompson Brooks/Cole.

Monks, C., Palermiti, A., Ortega, R., ve Costabile, A. (2011). A cross-national comparison of aggressors, victims and defenders in preschools in England, Spain and Italy. The Spanish Journal of Psychology, 14(1), 133-144.

Morita Y. (1985). Sociological study on the structure of bullying group. Osaka, Japan: Department of Sociology, Osaka City University.

Olweus, D. (1993). Bullying at schooll-what we know and what we can do. Oxford: Blackwell Publishers.

Olweus, D. (1994). Bullying at school: Long-term outcomes for the victims and effective school based intervention program.In (Ed. L. R. Huesmann) Aggressive Behavior: Current Perspectives. (p.97-130). New York: Pleum Press.

Olweus, D. (2005). Bullying at school. Australia, Oxford: Blackwell. 
Östberg, V., Modin, B., ve Låftman, S. B. (2018). Exposure to school bullying and psychological health in young adulthood: A prospective 10-year follow-up study. Journal of School Violence, 17(2), 194-209.

Özkan, Y., ve Çifci, E., G. (2010). Düşük sosyo-ekonomik düzeydeki ilköğretim okullarında akran zorbalığı. Ilköğretim Online, 9(2), 576-586.

Pearce, J. B., ve Thompson, A. E. (1998) Practical approaches to reduce the impact of bullying. Archives of Disease in Childhood, 79, 528-531.

Perren, S., Stadelmann, S., ve Von Klitzing, K. (2009). Child and family characteristics as risk factors for peer victimization in kindergarten. Schweizerische Zeitschrift fu" $r$ Bildungswissenschaften, 31(1), 13-32.

Peterson, J. S., ve Ray, K. E. (2006). Bullying and the gifted: Victims, perpetrators, prevalence, and effects. Gifted Child Quarterly, 50, 148-168.

Peyton, M. (2015). Exploring the meaning of school bullying among parents of victimized children. Doctoral Dissertation. Walden University, United States.

Pişkin, M. (2006). Akran zorbalığı olgusunun ilköğretim örgencileri arasındaki yaygınlı̆̆ıın incelenmesi. Şiddet ve Okul: Okul ve Çevresinde Çocuğa Yönelik Şiddet ve Alınabilecek Tedbirler Sempozyumu, İstanbul.

Pişkin, M. (2010). Ankara'daki ilköğretim öğrencileri arasında akran zorbalığının incelenmesi. Ĕ̆itim ve Bilim, 35(156), 175-189.

Pöyhönen, V., Juvonen, J., ve Salmivalli, C. (2010). What does it take to defend the victimized peer? The interplay between personal and social factors. Merrill-Palmer Quarterly, 56, 143-163.

Pöyhönen, V., Juvonen, J., ve Salmivalli, C. (2012). Standing up for a victim, siding with the bully, or standing by? Bystander responses in bullying situations. Social Development, 21, 722-741.

Rigby, K. (1998). The relationship between reported health and involvement in bully/victim problems at school among male and female secondary school children. Journal of Health Psychol, 3, 465-476.

Rigby, K., ve Johnson, B. (2005). Student bystanders in Australian schools. Pastoral Care in Education, 23(2), 10-16.

Rigby, K., ve Slee, P. T. (1991). Bullying among Australian school children: Reported behavior and attitudes towards victims. Journal of Social Psychology, 131, 615-627.

Rigby, K., ve Slee, P. T. (1999). Suicidal ideation among adolescent school children, involvement in bully/victim problems and perceived low social support. Suicide andLife-Threatening Behavior, 29, 119-130. 
Saarento, S., ve Salmivalli, C. (2015). The role of classroom peer ecology and bystanders' responses in bullying. Child Development Perspectives, 9(4), 201-205.

Sadık, F. (2002). Okul öncesi öğretmenlerinin sınıf içinde karşılaştıkları problem davranışlar. Öğretmen Dünyası, 23(272), 31-34.

Salmon, G., James, A., ve Smith, D. M. (1996). Bullying in schools: Self reportedanxiety, depression, and self esteem in secondary school children. British Medical Journal, 317, 924-925.

Salmon, G., James, A., Cassidy, E. L., ve Javaloyes, M. A. (2000). Bullying a review: Presentations to an adolescent psychiatric service and within a school for emotionally and behaviourally disturbed children. Clinical Child Psychology and Psychiatry, 5(4), 563-579.

Sandelowski, M. (2000). Whatever happened to qualitative description? Research in Nursing \& Health, 23(4), 334-340.

Sandelowski, M. (2010). What's in a name? Qualitative description revisited. Research in Nursing \& Health, 33(1), 77-84.

Serin, H. (2012). Ergenlerde siber zorbalık/siber mağduriyet yaşantıları ve bu davranışlara ilişkin öğretmen ve eğitim yöneticilerinin görüşleri. Yayınlanmamış Doktora Tezi. İstanbul Üniversitesi, Sosyal Bilimler Enstitüsü, İstanbul.

Schwartz, D. (2000). Subtypes of victims and aggressors in children's peer groups. Journal of Abnormal Child Psychology, 28, 181-192.

Segrin, C. (2001). Social skills and negative life events: Testing the deficit stress generation hypothesis. Current Psychology, 20(1), 17-19.

Slee P. T. (1994). Situational and interpersonal correlates of anxiety associated with peer victimisation. Child Psychiatry \& Human Development, 25, 97-107.

Smith, P. K. (2016). Bullying: Definition, types, causes, consequences and intervention. Social and Personality Psychology Compass, 10(9), 519-532.

Smith, P. K., ve Brain, P. (2000). Bullying in schools: Lessons from two decades of research. Aggressive Behavior: Official Journal of the International Society for Research on Aggression, 26(1), 1-9.

Stauffer, S., Heath, M. A., Coyne, S. M.,ve Ferrin, S. (2012). High school teachers' perceptions of cyberbullying prevention and intervention strategies. Psychology in the Schools, 49(4), 352-367. 
Şahin, M., Demirağ, S., ve Aykaç, F. (2009). Ana sınıfı öğretmenlerinin akran zorbalığı ile ilgili algıları. Sakarya Üniversitesi Ĕ̆gitim Fakültesi Dergisi, 17, 1-16.

Tepetaş, G. Ş., Akgun, E., ve Altun, S. A. (2010). Identifying preschool teachers' opinion about peer bullying. Procedia-Social and Behavioral Sciences, 2(2), 1675-1679.

Trach, J., Hymel, S., Waterhouse, T., ve Neale, K. (2010). Bystander responses to school bullying: A cross-sectional investigation of grade and sex differences. Canadian Journal of School Psychology, 25(1), 114-130.

Tural Hesapçıŏlu, S., Yeşilova Meraler, H., ve Ercan, F. (2018). Bullying in schools and its relation with depressive symptoms, self-esteem, and suicidal ideation in adolescents. Anadolu Psikiyatri Dergisi, 19(2), 210-216.

Ural, B., ve Özteke, N. (2007). Okulda zorbalı. Ankara: Kök Yayıncllı.

Uysal, H., ve Dinçer, Ç. (2012). Okul öncesi dönemde akran zorbalığı. Journal of Theoretical Educational Science, 5(4), 468-483.

Uysal, H., Altun, S. A., ve Akgün, E. (2010). Okulöncesi öğretmenlerinin çocukların istenmeyen davranışları karşısında uyguladıkları stratejiler. Ilköğretim Online, 9(3), 971-979.

Wang, J., Iannotti, J. R., ve Nansel, T. R. (2009). School bullying among US adolescents: physical, verbal, relational and cyber. Journal of Adolescent Health, 45(4), 368-375.

Whitney, I., ve Smith, P. K. (1993). A survey of the nature and extent of bullying in junior, middle and secondary schools. Educational Research, 35, 3-25.

Williams, K., Chambers, M., Logan, S., ve Robinson, D. (1996). Association of common health symptoms with bullying in primary school children. The British Medical Journal, 313(7048), 17-19.

Willis, D. G., Sullivan-Bolyai, S., Knafl, K., ve Cohen, M. Z. (2016). Distinguishing features and similarities between descriptive phenomenological and qualitative description research. Western Journal of Nursing Research, 38(9), 1185-1204.

Yalçıntaş Sezgin, E. (2018). Okulöncesi öğretmenlerin akran zorbalığı ilişkin alg1 ve görüşleri: zorbalık davranışları tespitleri, zorbalık davranışları karşısında uyguladıkları stratejiler ve aldıkları önlemler. Pamukkale Üniversitesi Sosyal Bilimler Enstitüsü Dergisi, 33, 85-104.

Yıldırım, A., ve Şimşek, H. (2013). Sosyal bilimlerde nitel araştırma yöntemleri. (9. baskı). Ankara: Seçkin Yayıncllık. 
Yoon, J. S. (2004). Predicting teacher interventions in bullying situations. Education and Treatment of Children, 27(1), 37-45.

Yurtal F., ve Cenkseven F. (2006). İlköğretim okullarında zorbalığın incelenmesi. 1. Şiddet ve Okul: Okul ve Çevresinde Çocuğa Yönelik Şiddete ve Alnabilecek Tedbirler Uluslararası Katılıml Sempozyumu, İstanbul, Türkiye.

Zych, I., Farrington, D. P., Llorent, V. J., ve Ttofi, M. M. (2017). School bullying in different countries: prevalence, risk factors, and short-term outcomes. In Protecting children against bullying and its consequences (pp.522). Springer, Cham.

\section{Kaynakça Bilgisi / Citation Information}

Çarkıt, E. ve Bacanlı, F. (2020). Okullarda akran zorbalı̆̆ı: Öğretmen görüşlerine göre nitel bir çalışma. OPUS-Uluslararası Toplum Araştırmaları Dergisi, 15(24), 2545-2583. DOI: 10.26466/opus. 644848 